\title{
Reactive Oxygen Species Production from Secondary Organic Aerosols: The Importance of Singlet Oxygen
}

\author{
Alessandro Manfrin ${ }^{1}$, Sergey A. Nizkorodov², Kurtis T. Malecha², Gordon J. Getzinger ${ }^{1}$, Kristopher \\ McNeill $^{1}$, Nadine Borduas-Dedekind ${ }^{1,3 *}$ \\ ${ }^{1}$ Institute for Biogeochemistry and Pollutant Dynamics, ETH Zurich, 8092 Zurich, Switzerland \\ ${ }^{2}$ Department of Chemistry, University of California, Irvine, CA 92697, USA \\ ${ }^{3}$ Institute for Atmospheric and Climate Science, ETH Zurich, 8092 Zurich, Switzerland \\ *Corresponding author: nadine.borduas@usys.ethz.ch
}

\section{Table of Contents}

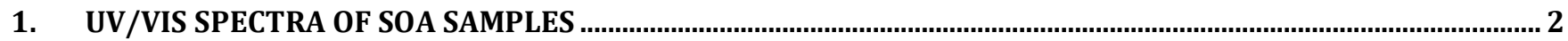

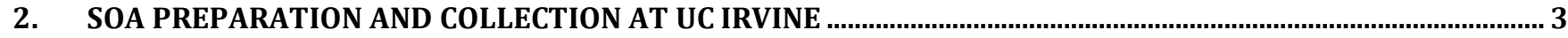

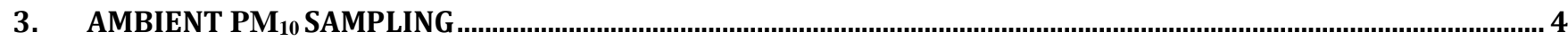

4. QUANTUM YIELDS CALCULATIONS FOR SOA, SRFA, PM FILTERS AND REFERENCE COMPOUNDS ................ 5

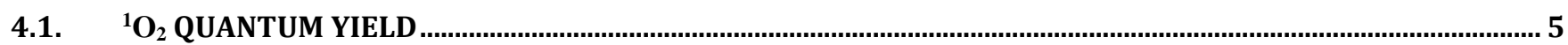

4.1.1. DETERMINATION OF FFA PSEUDO-FIRST-ORDER RATE CONSTANTS $\left(\mathrm{K}_{\mathrm{OBS}}\right)$.......................................................................... 5



4.1.3. CALCULATION OF THE ${ }^{1} \mathrm{O}_{2}$ QUANTUM YIELDS $(\phi 102)$.................................................................................................

4.1.4. STABILITY OF SOA SOLUTION SAMPLES UNDER OUR STORAGE CONDITIONS..........................................................................

4.1.5. KINETIC SOLVENT ISOTOPE EFFECT (KSIE) TESTS ...........................................................................................................

4.1.6. WAVELENGTH DEPENDENCE ON ${ }^{1} \mathrm{O}_{2}$ QUANTUM YIELD ................................................................................................... 10

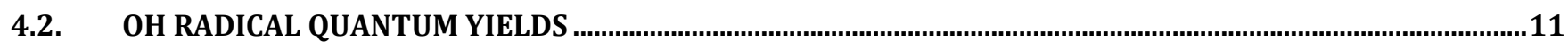

4.2.1. DETERMINATION OF THE RATE OF OH RADICAL PRODUCTION............................................................................................... 11

4.2.2. DETERMINATION OF THE RATE OF LIGHT ABSORPTION $\left(\mathrm{R}_{\mathrm{ABS}}\right)$.........................................................................................

4.2.3. CALCULATION OF THE OH RADICAL QUANTUM YIELDS $\left(\phi_{\mathrm{OH}}\right)$........................................................................................... 13

4.3. $\quad \mathrm{H}_{2} \mathrm{O}_{2}$ QUANTUM YIELDS

4.4. PM PII $_{10}$ FILTERS CORRECTION ON ROS STEADY-STATE CONCENTRATIONS AND QUANTUM YIELDS ….....15

5. SUVA 254 CALCULATION

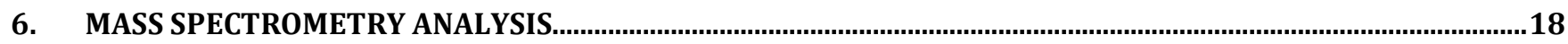

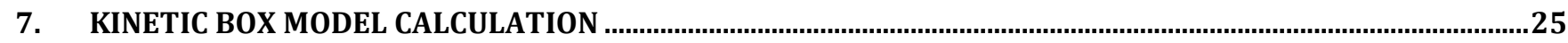

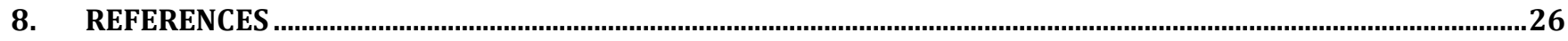




\section{1. $\mathrm{UV} / \mathrm{V}$ is spectra of SOA samples}

UV/Vis spectra were recorded with a dual beam spectrometer (Cary UV/Vis $100 \mathrm{Bio}$ ), using nanopure water (18.2 M $\Omega$-cm, from a Barnstead Nanopure Diamond system) as reference and using a $1 \mathrm{~cm}$ quartz cuvette for absorption measurements. In Figure S1, we report the wavelength-dependent mass absorption coefficients (MAC, $\mathrm{cm}^{2} \mathrm{~g}^{-1}$ ) for SOA samples. MAC is calculated as previously reported: ${ }^{1}$

$\operatorname{MAC}(\lambda)=\frac{A b S_{10}^{\text {solution }}(\lambda) \times \ln (10)}{d \times C_{\text {mass }}}$

where $A b s 10^{\text {solution }}(\lambda)$ is the base-10 absorbance of the solution, $d$ is the path length of light $(1 \mathrm{~cm})$ and $C_{\text {mass }}$ is the solution mass concentration $\left(\mathrm{g} \mathrm{cm}^{-3}\right)$ obtained from the mass concentration of C $\left(5 \times 10^{-6} \mathrm{~g}\right.$ $\mathrm{cm}^{-3}$ ) assuming a $\mathrm{OM} / \mathrm{OC}$ ratio of 1.6. ${ }^{2} \mathrm{MAC}$ is also corrected by subtracting the MAC at $600 \mathrm{~nm}$ where the mixtures show no absorption.

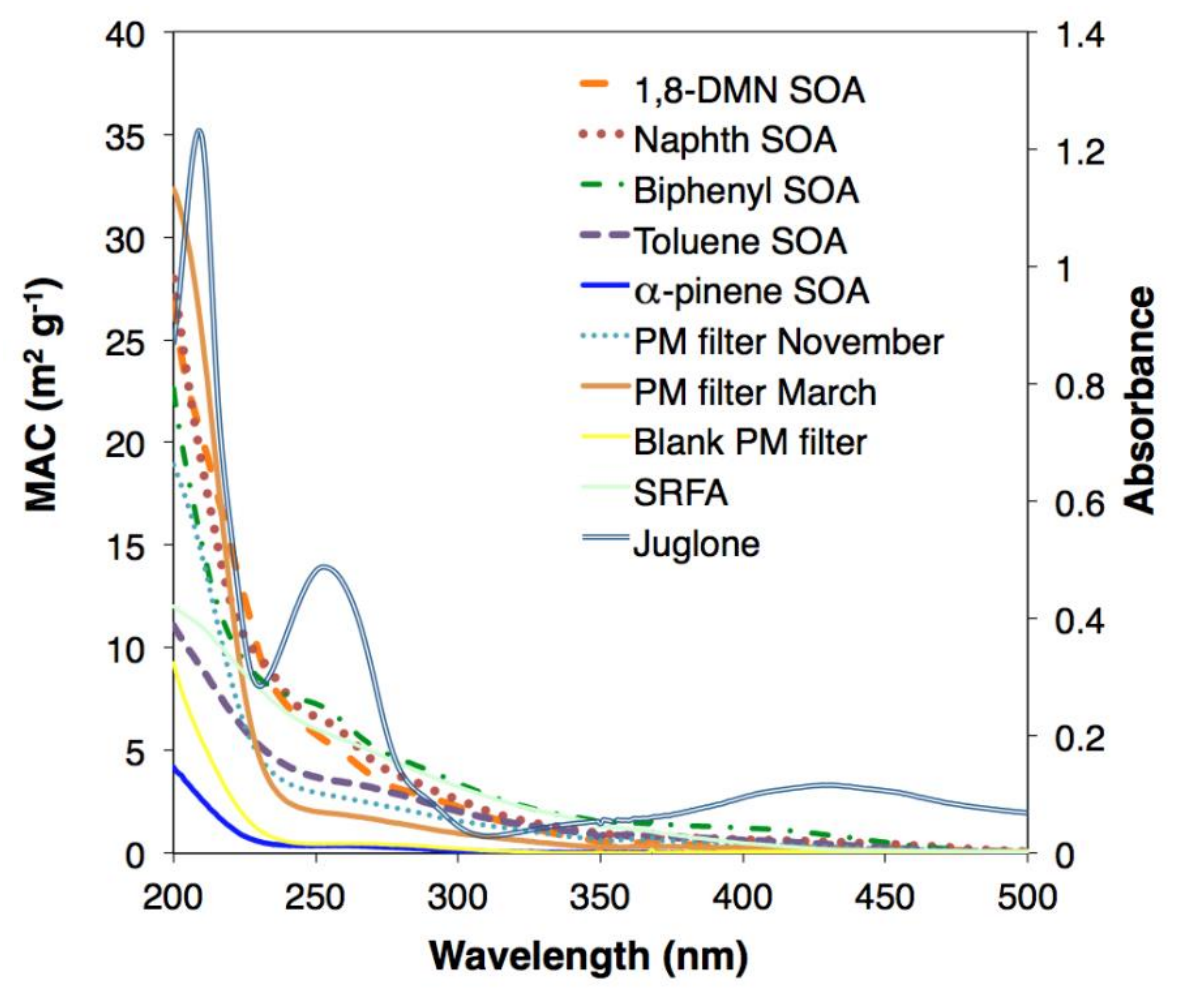

Figure S1. UV/Vis spectra of extracts of SOA samples generated from 1,8-dimethylnaphthalene (1,8DMN SOA), naphthalene (Naphth SOA), biphenyl, toluene and $\alpha$-pinene. The spectra of solutions of Suwannee River fulvic acid (SRFA), juglone, and the PM $_{10}$ filter extracts (PM filter November, PM filter March and PM filter blank) are also shown. On the right axis, the measured absorbance is for a concentration of $5 \mathrm{mgC}^{-1}$ for each sample. 


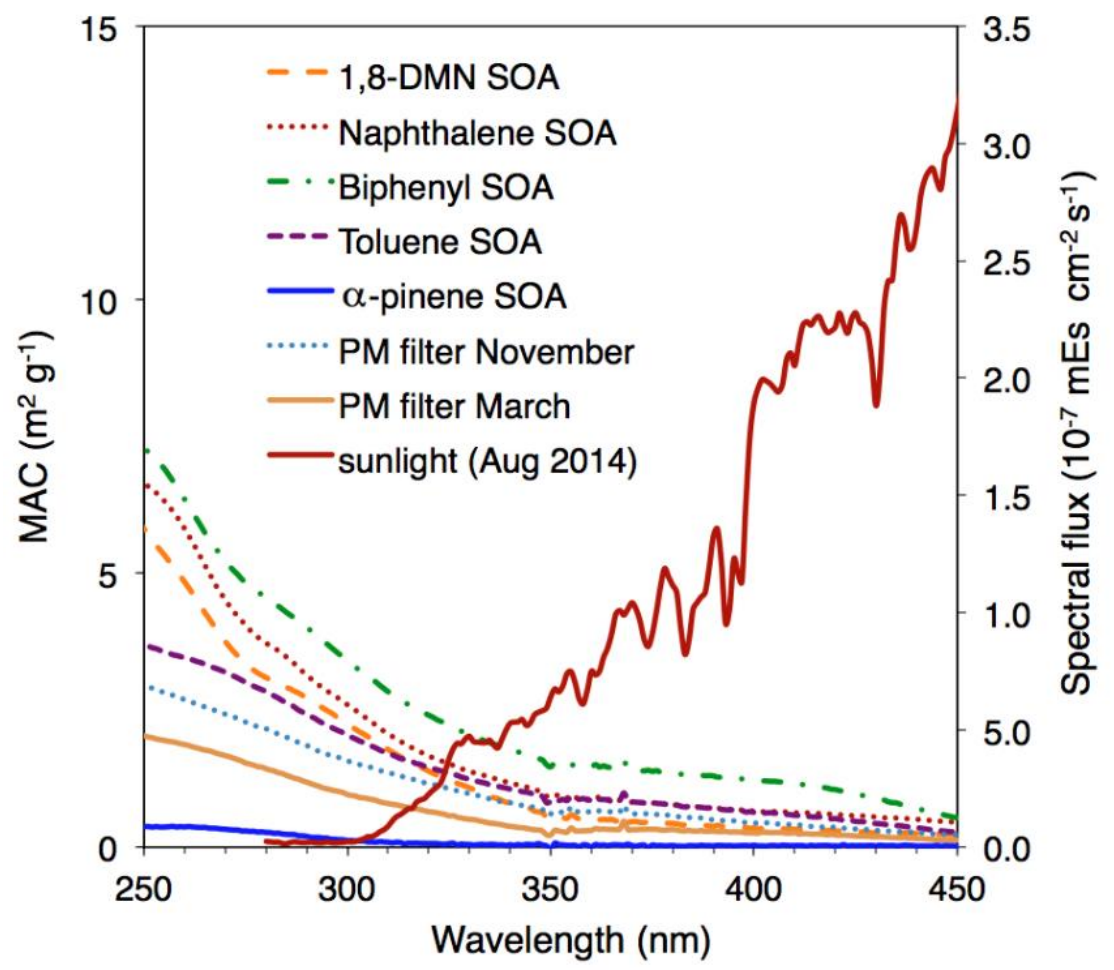

Figure S2. Insert of Figure S1 showing the overlap between the solar spectral flux and the UV/Vis spectra of extracts of SOA samples generated from 1,8-dimethylnaphthalene (1,8-DMN SOA), naphthalene, biphenyl, toluene and $\alpha$-pinene. The spectra of solutions of the $\mathrm{PM}_{10}$ filter extracts $(\mathrm{PM}$ filter November and PM filter March) are also shown. On the right axis, the measured spectral flux in Zurich, Switzerland in August 2014 taken with an Ocean Optics portable UV/Vis spectrophotometer.

\section{SOA preparation and collection at UC Irvine}

The aromatic compound vapors and oxidant precursor $\mathrm{H}_{2} \mathrm{O}_{2}$ were mixed in a $5 \mathrm{~m}^{3}$ Teflon FEP. The chosen starting mixing ratios (Table $\mathrm{S} 1)$ were relatively high to produce requisite amount of material $(\sim 3 \mathrm{mg})$ for subsequent photolysis experiments. The mixture was irradiated with UV-B lamps (centered at $310 \mathrm{~nm}$; FS40T12/UVB, Solar Tec Systems, Inc.) for 2-3 hours at room temperature. The particle collection started after the maximal particle mass concentration was reached. $\alpha$-Pinene SOA samples were also prepared by ozonolysis of $\alpha$-pinene, in which case $\mathrm{O}_{3}$ was added to the chamber instead of $\mathrm{H}_{2} \mathrm{O}_{2}$ and no UV lamps were used. The particle mass concentration in the chamber was determined with a scanning mobility particle sizer (SMPS; TSI model 3936). In addition, $\mathrm{NO}_{\mathrm{y}}$ (Thermo Scientific model 42i-Y) and ozone (Thermo Scientific model 49i) detectors were used to monitor the $\mathrm{NO}, \mathrm{NO}_{\mathrm{y}}$ and $\mathrm{O}_{3}$ mixing ratios during SOA formation. As typical for photooxidation experiments, the mixing ratio of the precursors and NO went down with irradiation time, while particle mass concentration and ozone mixing ratio increased. Once sufficient particle mass concentration was achieved, the particles were collected on $0.2 \mu \mathrm{m}$ pore size PTFE filters (FGLP04700 from Millipore) at $15 \mathrm{~L} / \mathrm{min}$ for 3-4 hours (Table S1). The filters were vacuum sealed and kept frozen until extraction, whereas the extract solutions were stored at $4{ }^{\circ} \mathrm{C}$. 
Table S1. Precursors, starting mixing ratios, reaction times and collection times used to prepare SOA filter samples at UC Irvine.

$\begin{array}{ccccccc}\text { Precursor Structure } & \text { Precur } & \mathrm{H}_{2} \mathrm{O}_{2} & \mathrm{NO} & \mathrm{O}_{3} & \text { Reacti } & \text { Collectio } \\ & \text { sor } & (\text { ppmv }) & (\mathbf{p p m v}) & (\mathbf{p p m v}) & \text { on } & \text { n Time } \\ & \text { conc. } & & & & \text { Time } & \text { (h) } \\ & (\mathbf{p p m}) & & & & (\text { h) } & \end{array}$

\begin{tabular}{|c|c|c|c|c|c|c|}
\hline Toluene & 2.0 & 4 & 0.60 & 0 & 3.5 & 4 \\
\hline Naphthalene & 0.40 & 2 & 0.40 & 0 & 2.25 & 4 \\
\hline Biphenyl & 0.90 & 4 & 0.60 & 0 & 3.25 & 3.25 \\
\hline 1,8-Dimethyl & 0.90 & 4 & 0.60 & 0 & 1.25 & 1.25 \\
\hline naphthalene & & & & & & \\
\hline$\alpha$-pinene & 0.50 & 0 & 0 & 3.0 & 1 & 4 \\
\hline Filter control & - & 0 & 0 & 0 & 0 & 4 \\
\hline
\end{tabular}

\section{Ambient $\mathrm{PM}_{10}$ sampling}

$\mathrm{PM}_{10}$ samples were collected on quartz microfiber filters $150 \mathrm{~mm}$ (Whatman ${ }^{\mathrm{TM}}$ ) with a High Volume Sampler Digitel DH 77 (Digitel Elektronik GmbH), which measures total suspended particulates with diameters $<10 \mu \mathrm{m}\left(\mathrm{PM}_{10}\right)$ using a size-selective inlet. The samples were taken in Roveredo, a town of 2000 inhabitants in the canton of Graubünden in Switzerland. Roveredo is located in the valley of Val Mesolcina and experiences air masses influenced by both rural and residential activities. The measuring site was situated on the southwestern border of the village center, near the western entry of the new bypasstunnel San Fedele on the motorway Autostrasse A13. PM10 samples were taken on November $29^{\text {th }} 2017$ and on March $4^{\text {th }} 2018$, with collection starting at 12:00 pm and lasting for $24 \mathrm{~h}$. Sampling dates were chosen in a time interval where no extraordinary events, such as bush fires or heavy industrial pollution was happening in the surrounding area. Therefore, the two selected filters can be regarded as typical particulate matter samples for this site, influenced by both residential and traffic activities. 
4. Quantum yields calculations for SOA, SRFA, PM filters and reference compounds

We calculated the reactive oxygen species (ROS) quantum yields of SOA mixtures, PM filters, SRFA and selected reference compounds (juglone and aromatic hydrocarbons) in order to normalize and compare the efficiency of different samples in producing ROS. The following sections explain the experimental and mathematical methods used to calculate the quantum yields of ${ }^{1} \mathrm{O}_{2}$ (section 2.1), $\mathrm{OH}$ radicals (section 2.2), $\mathrm{H}_{2} \mathrm{O}_{2}$ (section 2.3) and ROS for $\mathrm{PM}_{10}$ filters (section 2.4).

For the determination of quantum yields, we preferred to use a single wavelength lamp (311 nm) over a broadband source $(365 \mathrm{~nm})$ to simplify the rate of light absorption calculation, leading to fewer errors. These quantum yield measurements represent thus upper limits due to the use of $311 \mathrm{~nm}$ wavelength, representing UVB irradiation, the highest energy range reaching the troposphere and the surface of the planet. This choice is further based on an assumption that there is little wavelength dependency on ${ }^{1} \mathrm{O}_{2}$ production according to the literature. ${ }^{3,4}$ However, we do observe a difference between quantum yields determined from $311 \mathrm{~nm}$ vs broadband $365 \mathrm{~nm}$ experiments (Figure S5) and reemphasize therefore the upper limit quantum yield values determined in this work. Finally, the overlap between the SOA absorbance and the solar spectral flux is optimal between $310 \mathrm{~nm}$ and $340 \mathrm{~nm}$ (Figure S2).

\section{1. ${ }^{1} \mathrm{O}_{2}$ quantum yield}

To determine the ${ }^{1} \mathrm{O}_{2}$ quantum yields, two experimental details are necessary. First, the furfuryl alcohol (FFA) pseudo-first order rate constant is obtained by irradiating solutions of FFA and a sensitizer and monitoring FFA decay over time (section 2.1.1). Second, the rate of light absorption is determined by measuring the UV/Vis spectra of sensitizing samples (section 2.1.2).

\subsubsection{Determination of FFA pseudo-first-order rate constants ( $\left.\mathrm{k}_{\mathrm{obs}}\right)$}

We measured the ${ }^{1} \mathrm{O}_{2}$ production of the different systems by performing steady-state photochemical experiments using FFA as ${ }^{1} \mathrm{O}_{2}$ probe. ${ }^{5}$ Identical experimental setups containing $100 \square \mathrm{M}$ of FFA and a sensitizer were irradiated simultaneously in a Rayonet photoreactor with 10 bulbs at $365 \mathrm{~nm}$ or with a SMART narrow-band UVB hand-held lamp at $311 \mathrm{~nm}$. The sensitizers (SOA samples, PM 10 filters, SRFA) were used at $5 \mathrm{mgc} / \mathrm{L}$ or $1 \mu \mathrm{M}$ in the case of perinaphthenone (PN). PN served as a reference ${ }^{1} \mathrm{O}_{2}$ sensitizer with a known quantum yield. ${ }^{6} \mathrm{PN}$ is a convenient reference sensitizer since it does not degrade through direct photolysis (in comparison with rose bengal, for example), thereby ensuring a constant concentration of triplet state organic molecules. ${ }^{7}$ Furthermore, the ${ }^{1} \mathrm{O}_{2}$ quantum yield of PN has been measured for several solvents and solvent mixtures with three different methods by Schmidt et al., ${ }^{6}$ showing that it is independent of PN concentration (up to $2.7 \times 10^{-3} \mathrm{M}$ ) and in most cases above 0.95 . In particular, the ${ }^{1} \mathrm{O}_{2}$ quantum yield of $\mathrm{PN}\left(\phi_{P N}\right)$ in water was reported to be $0.98 \pm 0.08$ by the same authors, who also suggested $\mathrm{PN}$ as a universal reference for the ${ }^{1} \mathrm{O}_{2}$ quantum yield determinations. A $\mathrm{PN}{ }^{1} \mathrm{O}_{2}$ quantum of $0.98 \pm 0.08$ is commonly accepted and used ${ }^{8-10}$ and we believe it is applicable also to this study since we are working in similar conditions. The SOA concentration of $5 \mathrm{mgc} / \mathrm{L}$ was chosen as representative for atmospherically relevant conditions and the PN concentration was chosen based on its high efficiency in making ${ }^{1} \mathrm{O}_{2}{ }^{6}$ FFA concentration was monitored over time and the $\ln \left([\mathrm{FFA}]_{\mathrm{t}} /[\mathrm{FFA}]_{0}\right)$ was plotted vs time (Figure S3). The slopes of the curves represent the FFA pseudo-first-order rate 
constants $\left(\mathrm{k}_{\mathrm{obs}}, \mathrm{s}^{-1}\right)$ with SOA, PM10 filters, SRFA or PN. The kobs values obtained at $311 \mathrm{~nm}$ were corrected by subtracting the contribution of $\mathrm{OH}$ radical to the observed decay of FFA $\left(\mathrm{k}_{\mathrm{obs}}{ }^{\text {corr }}=\mathrm{k}_{\mathrm{obs}}\right.$ $\left(\mathrm{k}_{\mathrm{rxn}}{ }^{\mathrm{FFA}, \mathrm{OH}} \times\left[\mathrm{OH}^{\cdot}\right]_{\mathrm{ss}}\right)$, where $\mathrm{k}_{\mathrm{rxn}}{ }^{\mathrm{FFA}, \mathrm{OH}}=1.5 \times 10^{10} \mathrm{M}^{-1} \mathrm{~s}^{-1},{ }^{11}$ and $[\mathrm{OH}]_{\mathrm{ss}}$ is the one determined as described in the manuscript, materials and methods, point 6). We found a contribution to FFA decay due to $\mathrm{OH}$ radical from 9 to $32 \%$ (Table S2) for SOA material and PM filters when irradiated at $311 \mathrm{~nm}$. In the case of irradiation at $365 \mathrm{~nm}$, we found the contribution of $\mathrm{OH}$ radical to FFA degradation is between 1 and $2 \%$, therefore not significant for ${ }^{1} \mathrm{O}_{2}$ steady-state concentrations and quantum yields, since it is significantly lower than the error associated with these measurements. We therefore did not correct these values and did not add this contribution to Table S2. The corrected kobs were used for the calculation of the ${ }^{1} \mathrm{O}_{2}$ steady-state concentrations $\left(\left[{ }^{1} \mathrm{O}_{2}\right] \mathrm{ss}\right)$ and ${ }^{1} \mathrm{O}_{2}$ quantum yields $\left(\phi_{1_{\mathrm{O}_{2}}}\right)$.

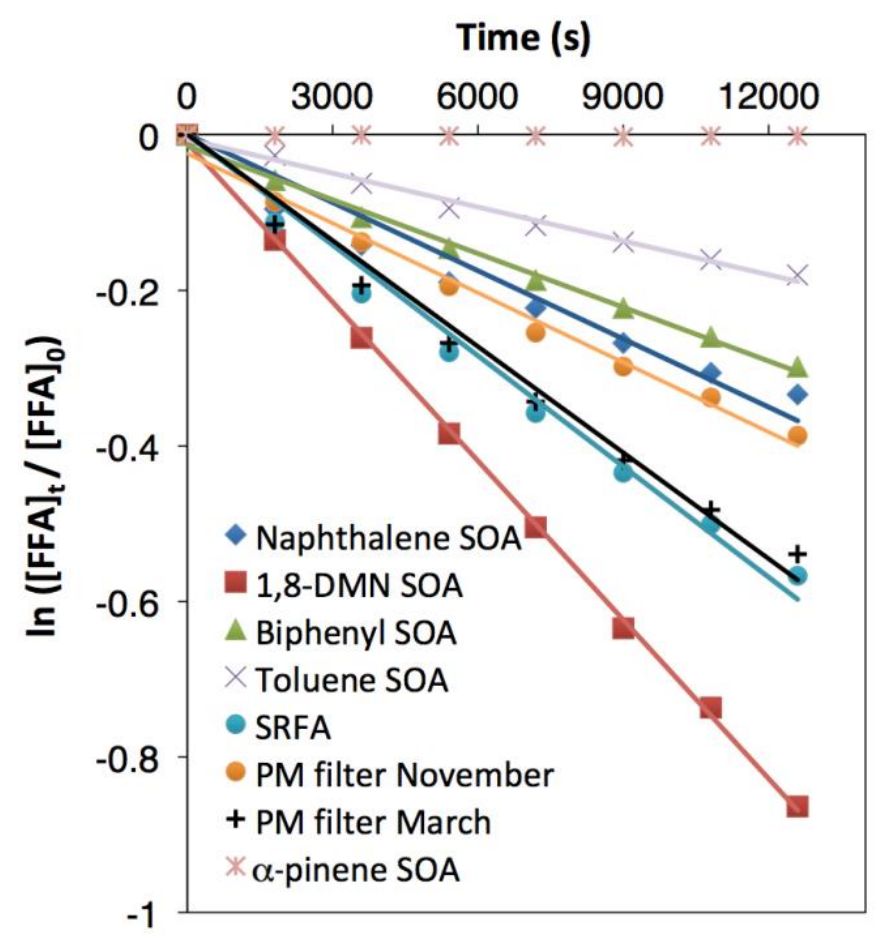

Figure S3. FFA degradation kinetics at $365 \mathrm{~nm}$ in the presence of SOA, SRFA and PM10 filters as ${ }^{1} \mathrm{O}_{2}$ sensitizers.

\subsubsection{Determination of the rate of light absorption $\left(\mathrm{R}_{\mathrm{abs}}\right)$}

The rate of light absorption for SOA, PM10 filters, SRFA and PN are also needed to calculate the ${ }^{1} \mathrm{O}_{2}$ quantum yield and are calculated as follows:

$R_{a b s}^{S O A}=\sum_{\lambda} I_{\lambda} S_{\lambda} A b s_{\lambda}^{S O A}$

where $I_{\lambda}$ is the light intensity, $S_{\lambda}$ is the screening factor and $A b s_{\lambda}$ is the absorbance at each wavelength. $I_{\lambda}$ is the relative light intensity of the UVB bulbs or the $311 \mathrm{~nm}$ lamp recorded with an Ocean Optics portable $\mathrm{UV} / \mathrm{V}$ is spectrophotometer. Note that there is no need to scale $\mathrm{I}_{\lambda}$ to an absolute value, since the ratio $\mathrm{R}_{\mathrm{abs}}{ }^{\mathrm{PN}} / \mathrm{R}_{\mathrm{abs}}{ }^{\mathrm{SOA}}$ is used in the quantum yield calculation. $\mathrm{S}_{\lambda}$ was calculated with equation $\mathrm{S} 3$ : 
where $d$ is the path length of light through the spectrometer cuvette $(1 \mathrm{~cm})$.

For the experiments performed at $365 \mathrm{~nm}, \mathrm{R}_{\mathrm{abs}}$ was calculated between 300 and $450 \mathrm{~nm}$ to account for emission spikes out of the maximum emission peak of the light bulbs, and consistent with Kaur et al.'s integrated range. ${ }^{12}$ However, we favor the use of $311 \mathrm{~nm}$ bulbs for indirect photochemistry experiments since the bandwidth of irradiation is significantly narrower (Figure S4). Thus, we calculated the $\mathrm{R}_{\mathrm{abs}}$ at a single wavelength $(311 \mathrm{~nm})$. In this case, $\mathrm{R}_{\mathrm{abs}}$ is simply obtained by multiplying the screening factor at $311 \mathrm{~nm}$ with the absorbance at the same wavelength, without the need of the light intensity and therefore reducing the sources of errors in the calculation.

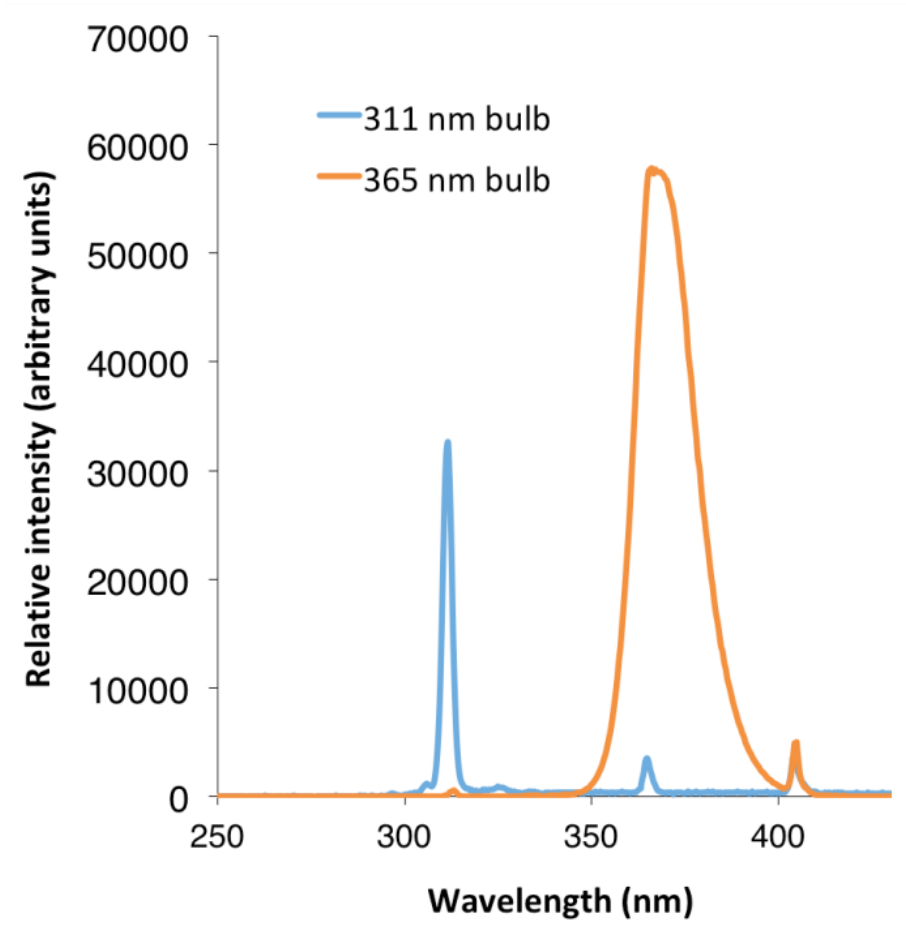

Figure S4. Emission spectra of the $365 \mathrm{~nm}$ light bulbs (orange) and the $311 \mathrm{~nm}$ SMART narrow-band UVB hand-held lamp (blue) recorded with an Ocean Optics portable UV/Vis spectrophotometer. Intensity is reported as arbitrary intensity in counts per nanometer.

\subsubsection{Calculation of the ${ }^{1} \mathrm{O}_{2}$ quantum yields $\left(\phi_{1_{O_{2}}}\right)$}

The ${ }^{1} \mathrm{O}_{2}$ quantum yields at $365 \mathrm{~nm}$ of the SOA mixture, $\mathrm{PM}_{10}$ filters and SRFA were calculated with the following equation:

$\phi_{1_{O_{2}}}=\frac{k_{o b s, 365}^{S O A}}{k_{o b s, 365}^{P N}} \times \frac{R_{a b s}^{P N}}{R_{a b s}^{S O A}} \times \phi_{P N}$

In the case of the $311 \mathrm{~nm}$ bulbs, the equation of the ${ }^{1} \mathrm{O}_{2}$ quantum yield is simplified as follows:

$\phi_{1_{O_{2}}}=\frac{k_{o b s, 311}^{S O A}}{k_{o b s, 311}^{P N}} \times \frac{S_{311}^{P N} \times A b s_{311}^{P N}}{S_{311}^{S O A} \times A b s_{311}^{S O A}} \times \phi_{P N}$ 
Table S2. Summary of corrected kobs, ${ }^{1} \mathrm{O}_{2}, \mathrm{R}_{\mathrm{abs}}, \mathrm{s}_{311}, \phi^{1} \mathrm{O}_{2}$ and $\%$ of $\mathrm{OH}$ radical contribution to FFA degradation for SOA, PM 10 filters, SRFA, PN and juglone. Errors reported for kobs are the standard deviations of three independent measurements. No uncertainty is reported for Rabs at $311 \mathrm{~nm}$, for $365 \mathrm{~nm}$ and for 3311 since these numbers derive from spectrometric readings, while errors associated with quantum yields are propagated errors that include uncertainties on kobs and $\phi P N$. Steady-state ${ }^{1} \mathrm{O}_{2}$ concentrations were calculated by dividing the corrected FFA pseudo-first-order rate constant $\left(\mathrm{k}_{\mathrm{obs}}{ }^{\text {corr }}\right)$ by its reaction rate constant with ${ }^{1} \mathrm{O}_{2}\left(\mathrm{k}_{\mathrm{rxn}}{ }^{\mathrm{FFA}}=1 \times 10^{8} \mathrm{M}^{-1} \mathrm{~s}^{-1}\right)$ by Appiani et al. ${ }^{5}$ The reported $\phi \mathrm{PN}$ is the value published by Schmidt et al. ${ }^{6}$

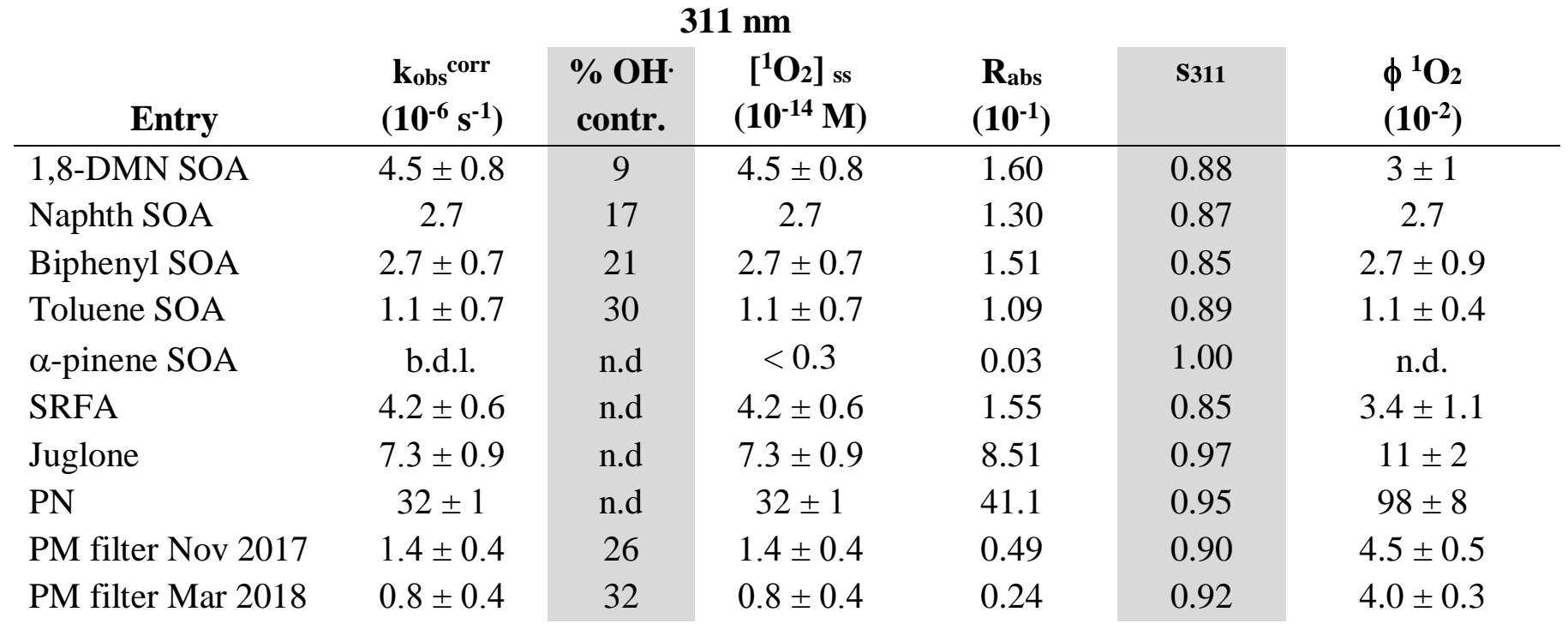

\section{$365 \mathrm{~nm}$}

\begin{tabular}{|c|c|c|c|c|}
\hline Entry & $\begin{array}{c}k_{\text {obs }} \\
\left(10^{-5} \mathrm{~s}^{-1}\right)\end{array}$ & $\begin{array}{c}{\left[{ }^{1} \mathbf{O}_{2}\right]_{\mathrm{ss}}} \\
\left(\mathbf{1 0}^{-13} \mathrm{M}\right)\end{array}$ & $\begin{array}{l}R_{\text {abs }} \\
\left(10^{4}\right)\end{array}$ & $\begin{array}{l}\phi^{1} \mathbf{O}_{2} \\
\left(10^{-2}\right)\end{array}$ \\
\hline 1,8-DMN SOA & $6.3 \pm 0.9$ & $6.3 \pm 0.9$ & 8.76 & $3.2 \pm 1.3$ \\
\hline Naphth SOA & $2.4 \pm 0.1$ & $2.4 \pm 0.1$ & 9.08 & $1.2 \pm 0.3$ \\
\hline Biphenyl SOA & $2.4 \pm 0.2$ & $2.4 \pm 0.2$ & 1.11 & $1.0 \pm 0.4$ \\
\hline Toluene SOA & $1.6 \pm 0.2$ & $1.6 \pm 0.2$ & 8.37 & $0.9 \pm 0.3$ \\
\hline$\alpha$-pinene SOA & b.d.l. & b.d.l. & n.d. & n.d. \\
\hline SRFA & $4.6 \pm 0.2$ & $4.6 \pm 0.2$ & 10.7 & $1.9 \pm 0.6$ \\
\hline Juglone & 12.2 & 12.2 & 1.82 & 3.0 \\
\hline PN & $106 \pm 2$ & $106 \pm 2$ & 48.3 & $98 \pm 8$ \\
\hline PM filter Nov 2017 & $3.1 \pm 0.1$ & $3.1 \pm 0.1$ & 7.76 & $3.2 \pm 0.5$ \\
\hline PM filter Mar 2018 & $4.3 \pm 0.6$ & $4.3 \pm 0.6$ & 6.08 & $5.9 \pm 0.7$ \\
\hline
\end{tabular}

b.d.l. $=$ below detection limit; n.d. $=$ not determined 
SOA samples were stored in the refrigerator at $+4{ }^{\circ} \mathrm{C}$ for 2 months. The ${ }^{1} \mathrm{O}_{2}$ steady-state concentration, generated from SOA samples, was measured twice more than 30 days apart and no significant difference was found, indicating stability of the mixture under our storage conditions.

Table S3. Comparison of ${ }^{1} \mathrm{O}_{2}$ steady-state concentrations of $365 \mathrm{~nm}$-irradiated solutions a few months apart show no significant change nor trend in sensitizing ability of SOA material.

${ }^{1} \mathrm{O}_{2}$ concentration $\left(10^{-13} \mathrm{M}\right)$

\begin{tabular}{c|cccc} 
Date & 1,8-DMN SOA & Naphth SOA & Biphenyl SOA & Toluene SOA \\
\hline 31.01 .18 & 6.32 & 2.50 & 2.66 & 1.84 \\
06.03 .18 & 6.78 & 2.53 & 2.32 & 1.46
\end{tabular}

4.1.5. Kinetic solvent isotope effect (KSIE) tests

In order to rule out FFA degradation by oxidants other than ${ }^{1} \mathrm{O}_{2}$ (e.g., triplet state organic matter), we performed kinetic solvent isotope effect experiments. FFA degradation was measured, as described above, also in a $1: 1 \mathrm{D}_{2} \mathrm{O} / \mathrm{H}_{2} \mathrm{O}(\mathrm{v} / \mathrm{v})$ mixture with SOA samples and $\mathrm{PM}_{10}$ filters as ${ }^{1} \mathrm{O}_{2}$ sensitizers. According to Davis et al., ${ }^{13}$ the ratio of the observed FFA degradation in the $\mathrm{D}_{2} \mathrm{O} / \mathrm{H}_{2} \mathrm{O}$ mixture $(\mathrm{k} 50 \% \mathrm{D} 2 \mathrm{O})$ and pure $\mathrm{H}_{2} \mathrm{O}$ $\left(\mathrm{kH}_{2} \mathrm{O}\right)$ is 1.9 if the only process degrading FFA is ${ }^{1} \mathrm{O}_{2}$ oxidation. This effect is due to the difference in ${ }^{1} \mathrm{O}_{2}$ lifetime between water $\left(\mathrm{H}_{2} \mathrm{O}\right)$ and heavy water $\left(\mathrm{D}_{2} \mathrm{O}\right)$. Our results show that for all the SOA samples and $\mathrm{PM}_{10}$ filters the ratio is consistent with pure ${ }^{1} \mathrm{O}_{2}$ oxidation of FFA.

Table S4. Summary of the KSIE observed for SOA mixtures and PM $\mathrm{PM}_{10}$ filters irradiating at $365 \mathrm{~nm}$.

\begin{tabular}{|c|c|}
\hline Entry & $\mathbf{K}_{50} \% \mathrm{D} 20 / \mathbf{k}_{\mathrm{H} 2 \mathrm{O}}$ \\
\hline 1,8-DMN SOA & 2.0 \\
\hline Naphthalene SOA & 1.9 \\
\hline Biphenyl SOA & 1.9 \\
\hline Toluene SOA & 1.9 \\
\hline$\alpha$-pinene SOA & n.d. \\
\hline PM filter Nov & 1.8 \\
\hline PM filter Mar & 1.8 \\
\hline
\end{tabular}


4.1.6. Wavelength dependence on ${ }^{1} \mathrm{O}_{2}$ quantum yield

As described in the irradiation section of the methods, the quantum yield dependence on wavelength is currently debated in the literature and is ongoing research in our laboratory. We report our values at 311 $\mathrm{nm}$ to highlight the upper limit possible for the ${ }^{1} \mathrm{O}_{2}$ quantum yield while highlighting some evidence of wavelength dependence when conducting the photochemical experiments with broad band $365 \mathrm{~nm}$ bulbs.

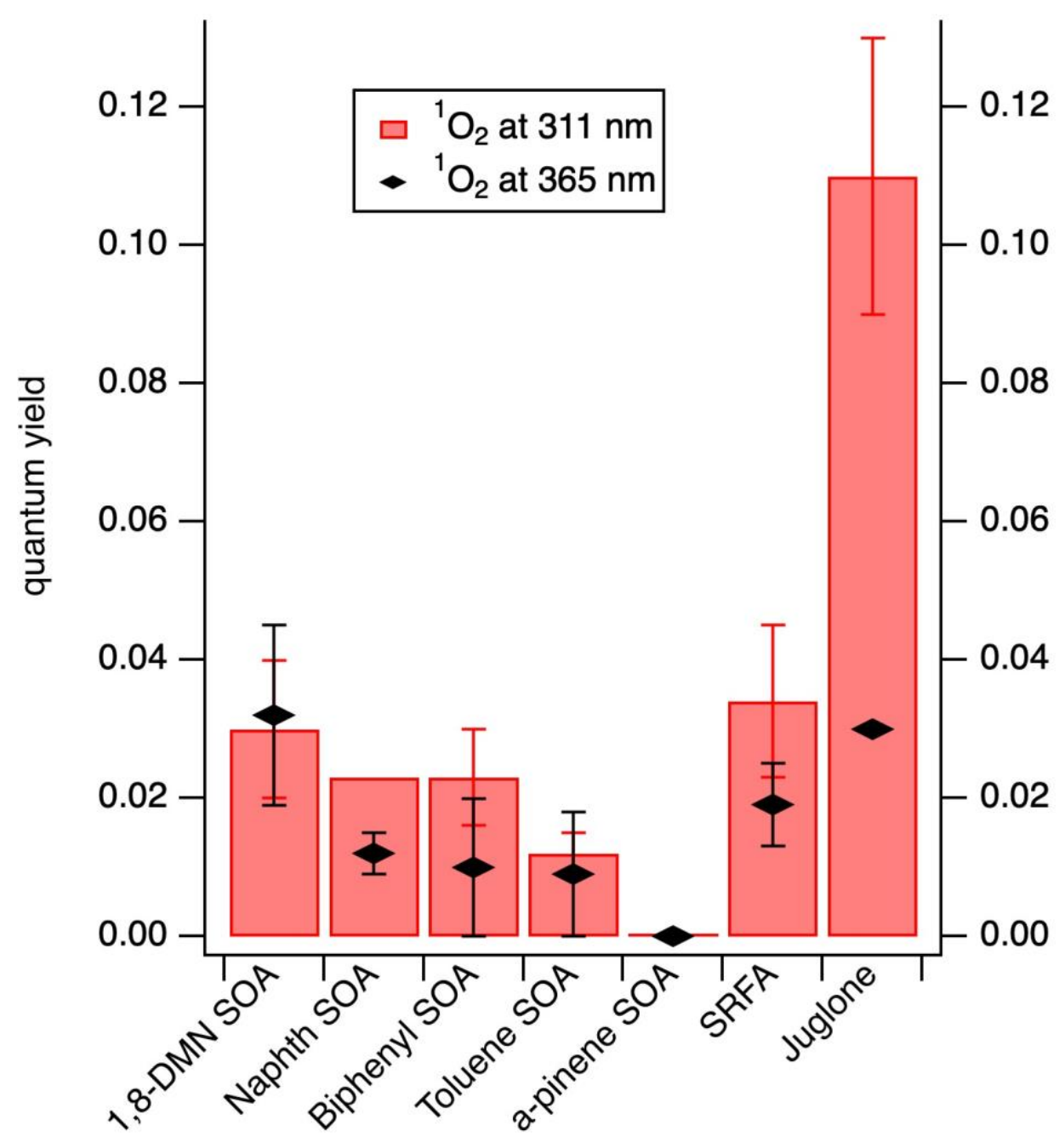

Figure S5. Comparison of quantum yields on a linear scale between samples irradiated at $311 \mathrm{~nm}$ with the SMART narrow-band lamp and at $365 \mathrm{~nm}$ with broadband UVA bulbs in a Rayonet. Error bars are propagated errors. 


\section{2. $\mathrm{OH}$ radical quantum yields}

The determination of the $\mathrm{OH}$ radical quantum yields requires two types of experiments analogously to the ${ }^{1} \mathrm{O}_{2}$ quantum yield determination. First, the rate of $\mathrm{OH}$ radical production is determined by following hydroxyterephthalate (hTPA) production; second, the rate of light absorbance is determined from UV-vis measurements.

\subsubsection{Determination of the rate of $\mathrm{OH}$ radical production}

To determine the rate of $\mathrm{OH}$ radical production, we measured the hTPA production rates at different potassium terephthalate (TPA) concentrations. ${ }^{14}$ According to Page et al. (2010), hTPA instability would make TPA unsuitable to study irradiated systems at waveleng ths below $360 \mathrm{~nm}$, however where a hTPA solution was irradiated with our SMART lamp at $311 \mathrm{~nm}$, no hTPA degradation was registered probably due to the low intensity of the light used. The rates of $\mathrm{OH}$ radical production ( $\mathrm{RoH}$ ) were obtained by dividing the asymptotes of the curves (Figure S6b) by the reaction yield of OH radical with TPA (assumed here to be $35 \%$ as reported by Page et al. $)^{14}$.

The hydroxyl radical steady-state concentrations, $[\mathrm{OH}]_{\mathrm{ss}}$, were determined under conditions of no probe, following the approach described by Zhou and Mopper. ${ }^{15}$ Briefly, 1/R $\mathrm{R}_{\mathrm{hPA}}$ was plotted versus $1 /$ [TPA] to obtain a linear correlation (Table S7). The curves were fitted with the following equation (6):

$\frac{1}{R_{h T P A}}=\frac{1}{R_{O H}}+\frac{k_{O H}^{\prime}}{R_{O H} \times k_{r X n}^{T P A}} \times \frac{1}{[T P A]}$

where $\mathrm{R}_{\mathrm{OH}}$ is the rate of hydroxyl radical production, $\mathrm{k}^{\prime} \mathrm{OH}$ is the $\mathrm{OH}$ radical scavenging rate constant of $\mathrm{SOA} / \mathrm{PM}_{10}$ filters and $\mathrm{k}_{\mathrm{rxn}}{ }^{\mathrm{TPA}}$ is the reaction rate constant of TPA with $\mathrm{OH}$ radical $\left(\mathrm{k}_{\mathrm{rxn}}{ }^{\mathrm{TPA}}=4.4 \pm 0.1 \times\right.$ $\left.10^{9} \mathrm{M}^{-1} \mathrm{~s}^{-1}\right) .{ }^{14}$ The inverse of the intercept was divided by the reaction yield of hydroxyl radical and TPA $(35 \%),{ }^{14}$ to obtain the rate of hydroxyl radical production $\left(\mathrm{R}_{\mathrm{OH}}\right)$. 

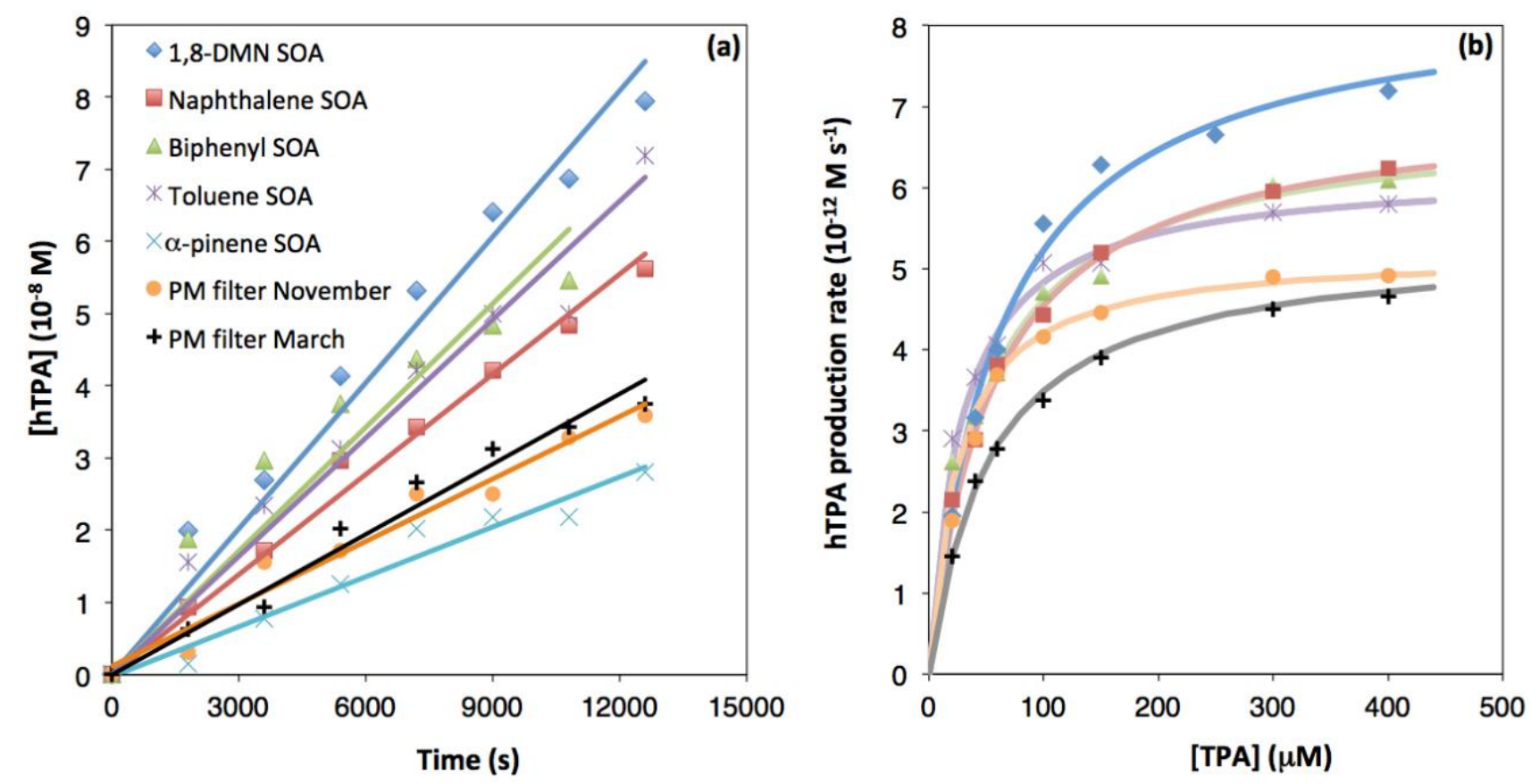

Figure S6. (a) hTPA production rates for SOA mixtures and $\mathrm{PM}_{10}$ filters determined from the concentration of hTPA as a function of time, (b) hTPA production rates versus TPA concentrations.
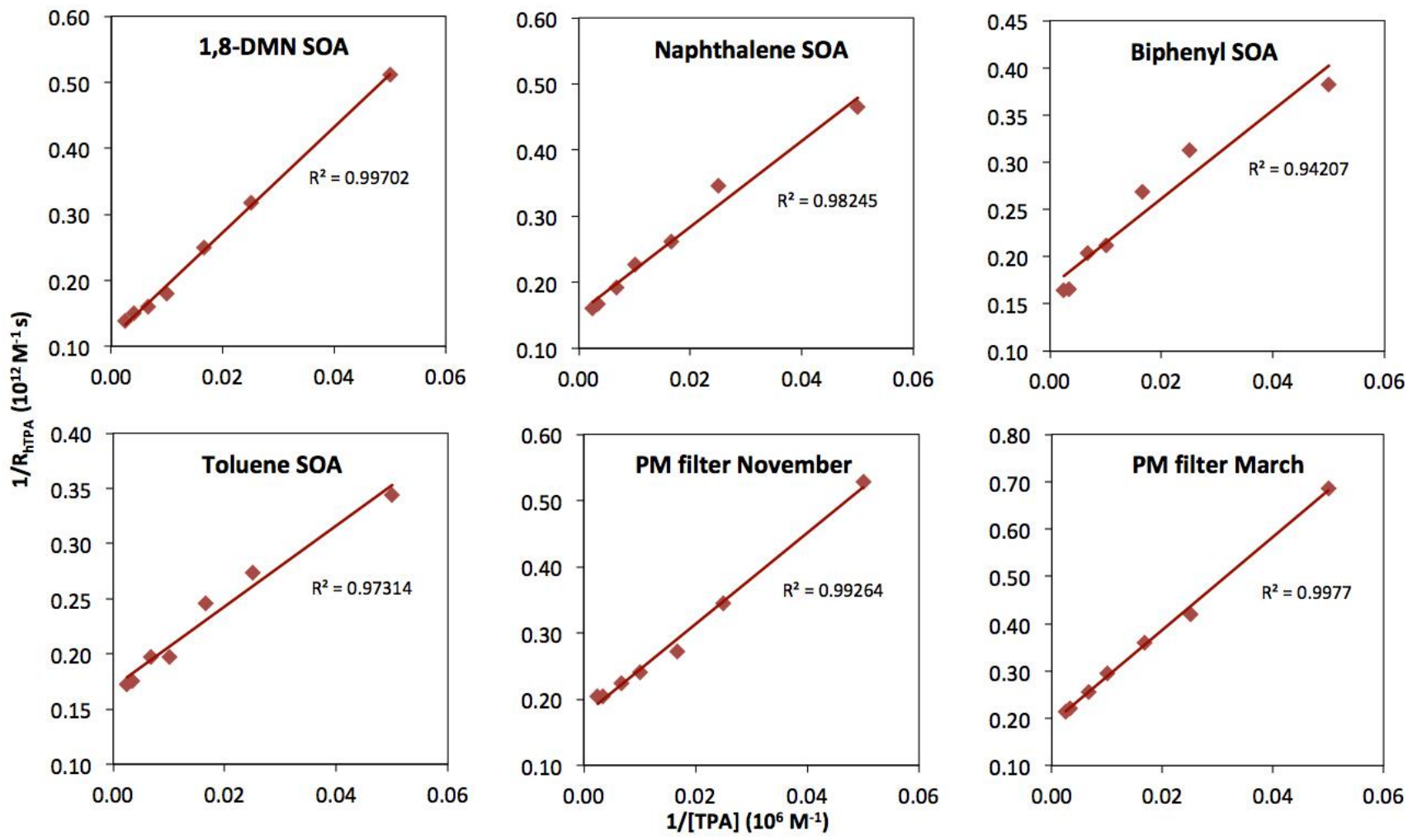

Figure S7. The linear correlation between 1/RhTPA and 1/[TPA] for SOA and PM extracts.

4.2.2. Determination of the rate of light absorption ( $\left.\mathrm{R}_{\mathrm{abs}}\right)$ 
The rate of light absorption ( $\mathrm{R}_{\mathrm{abs}}$ ) for $\mathrm{OH}$ radicals is calculated with the following equation:

$$
R_{a b s}=\chi \sum_{\lambda} I_{\lambda} S_{\lambda} A b s_{\lambda}
$$

where $\mathrm{I}_{\lambda}, \mathrm{S}_{\lambda}$ and $\mathrm{Abs}_{\lambda}$ are the relative light intensity, the screening factor and the absorbance at each wavelength, respectively and where $\chi$ is a scaling factor to obtain the absolute spectral irradiance. $\chi$ is calculated as follows:

$\chi=\frac{k_{o b S}^{P N A}}{\phi_{P N A} \sum_{\lambda} I_{\lambda} \varepsilon_{\lambda}^{P N A}}$

$\mathrm{I}_{\lambda}$ and $\varepsilon_{\lambda}$ are the relative light intensity and the molar extinction coefficient of PNA at each wavelength. The scaling factor $\chi$ is determined with the para-nitroanisole/pyridine (PNA-Py) chemical binary actinometer under the same light conditions as RoH. ${ }^{16}$ PNA degradation is followed over time with ultrahigh-pressure liquid chromatography (UPLC, Waters ACQUITY) coupled with a photodiode array detector (conditions: $0.15 \mathrm{~mL} / \mathrm{min}, 70: 30 \mathrm{MQ}: \mathrm{AcN}$, PNA detected at $316 \mathrm{~nm}$, RT = $3.46 \mathrm{~min}$ ). PNA pseudo-first order degradation rate constant is obtained as the slope of the curve $\ln \left([\mathrm{PNA}]_{\mathrm{t}} /[\mathrm{PNA}]_{0}\right)$ vs time (s) and we obtain a value of $\mathrm{kobs}^{\mathrm{PNA}}=(9.4 \pm 0.2) \times 10^{-6} \mathrm{~s}^{-1}$. $\phi$ PNA is the PNA quantum yield calculated as suggested by Laszakovits et al. $(\phi \mathrm{PNA}=0.29[\mathrm{Py}]+0.00029) .{ }^{16}$ The pyridine concentration $[\mathrm{Py}]$ needs to be adjusted according to the light conditions used, higher [Py] correspond to faster PNA degradation. In particular, we used a [Py] of $500 \mu \mathrm{M}$, which corresponds to a $\phi$ PNA of $4.35 \times 10^{-4}$.

In the case of a monochromatic light $(311 \mathrm{~nm})$, the equation can be simplified by excluding the measurement of light intensity and the calculation of the scaling factor, thus reducing the source of errors and consequently the uncertainty on the quantum yields. $R_{a b s}$ for a single wavelength can be calculated as follows:

$R_{a b s}=\frac{k_{o b s}^{P N A} \times S_{311} \times\left(A b s_{311}^{S O A} / 1 \mathrm{~cm}\right)}{\varepsilon_{311}^{P N A} \times \phi_{P N A}}$

where $\varepsilon_{311}{ }^{\mathrm{PNA}}$ is the PNA molar extinction coefficient reported by Laszakovits et al. and equals 10507.36 $\mathrm{M}^{-1} \mathrm{~cm}^{-1} \cdot{ }^{16}$

\subsubsection{Calculation of the $\mathrm{OH}$ radical quantum yields $(\phi \mathrm{OH})$}

To determine RoH, the hTPA production rates were measured at seven TPA concentrations ranging from 20 to $400 \mu \mathrm{M}$. RoH was obtained from two equivalent methods: using the competition kinetics (as described in the main text) and calculating the asymptote of the curve that correlates the TPA concentrations with the hTPA production rates. In this case, RoH was calculated from the maximum hTPA production rate divided by the reaction yield of $\mathrm{OH}$ radical with TPA (35\%). Unfortunately, we could not measure the $\mathrm{OH}$ radical quantum yield for $\alpha$-pinene SOA due to lack of material. While no $\mathrm{OH}$ radical quantum yield has been reported for $\alpha$-pinene SOA, others have quantified $\mathrm{OH}$ radical yield from peroxides produced by $\alpha$-pinene SOA, ${ }^{17}$ and its molar yield after irradiation at $254 \mathrm{~nm} .{ }^{18}$

Finally, the $\mathrm{OH}$ radical quantum yields were calculated at $311 \mathrm{~nm}$ employing the following equation: 
$\phi_{O H}=\frac{R_{O H}}{R_{a b s}}$

where $\mathrm{RoH}\left(\mathrm{M} \mathrm{s}^{-1}\right)$ is the rate of $\mathrm{OH}$ radical production and $\mathrm{Rabs}\left(\mathrm{M} \mathrm{s}^{-1}\right)$ is the rate of light absorption.

Table S5. Summary of RoH, $\mathrm{R}_{\mathrm{abs}}$, k' $\mathrm{OH}$ (rate of scavenging), $\mathrm{k}_{\mathrm{OH}} / \mathrm{DOC},[\mathrm{OH}]_{\mathrm{ss}}$ and $\phi \mathrm{OH}$ for $\mathrm{SOA}$ and $\mathrm{PM}_{10}$ filters. All errors reported are propagated errors. Rabs have a correlate uncertainty in this case since they derive also from the $\mathrm{k}_{\mathrm{obs}}{ }^{\mathrm{PNA}}$ and not only from spectrometric readings as in the case of ${ }^{1} \mathrm{O}_{2}$.

\begin{tabular}{|c|c|c|c|c|c|c|}
\hline Entry & $\begin{array}{c}\text { RoH } \\
\left(10^{-11} \mathrm{M} \mathrm{s}^{-1}\right) \\
\end{array}$ & $\begin{array}{c}\mathbf{R}_{\text {abs }} \\
\left(10^{-7} \mathrm{M} \mathrm{s}^{-1}\right)\end{array}$ & $\begin{array}{c}\mathrm{k}^{\prime} \mathrm{OH} \\
\left(10^{5} \mathrm{~s}^{-1}\right)\end{array}$ & $\begin{array}{c}\mathrm{k}^{\prime} \mathrm{он} / \mathrm{DOC} \\
\left(10^{8} \mathrm{~L} \mathrm{MC}^{-1} \mathrm{~s}^{-1}\right)\end{array}$ & $\begin{array}{r}{[\mathrm{OH} \cdot]_{\mathrm{ss}}} \\
\left(\mathbf{1 0}^{-17} \mathrm{M}\right)\end{array}$ & $\begin{array}{c}\phi \mathrm{он} \\
\left(10^{-5}\right)\end{array}$ \\
\hline $1,8-\mathrm{DMN}$ SOA & $2.4 \pm 0.5$ & $5.3 \pm 0.1$ & 8.9 & 7.5 & $2.9 \pm 0.4$ & $4.6 \pm 0.9$ \\
\hline Naphth SOA & $2.0 \pm 0.3$ & $3.20 \pm 0.07$ & 5.3 & 4.5 & $3.5 \pm 0.6$ & $6.3 \pm 1.0$ \\
\hline Biphenyl SOA & $2.0 \pm 0.4$ & $3.86 \pm 0.09$ & 3.5 & 2.9 & $4.9 \pm 0.3$ & $5.1 \pm 1.0$ \\
\hline Toluene SOA & $1.8 \pm 0.3$ & $2.61 \pm 0.06$ & 5.4 & 4.6 & $3.1 \pm 0.7$ & $6.8 \pm 1.3$ \\
\hline$\alpha$-pinene SOA & n.d. & $1.43 \pm 0.07$ & n.d. & n.d. & $2.6 \pm 0.8$ & n.d. \\
\hline PM filter Nov & $1.3 \pm 0.5$ & $1.19 \pm 0.03$ & 4.9 & 4.2 & $3.3 \pm 0.3$ & $11 \pm 4$ \\
\hline PM filter Mar & $1.4 \pm 0.3$ & $0.57 \pm 0.01$ & 6.5 & 5.5 & $2.3 \pm 0.4$ & $24 \pm 5$ \\
\hline
\end{tabular}

n.d. $=$ not determined

\section{3. $\mathrm{H}_{2} \mathrm{O}_{2}$ quantum yields}

The production of $\mathrm{H}_{2} \mathrm{O}_{2}$ under irradiation was quantified using the horseradish peroxidase (HRP) Amplex Red method, as described in the method section of the main paper and in previous literature. ${ }^{19,20} \mathrm{We}$ make the assumption that the $\mathrm{H}_{2} \mathrm{O}_{2}$ signal is negligibly influenced by organic peroxides. To corroborate this assumption, (1) organic peroxides are likely present in significantly lower concentrations than $\mathrm{H}_{2} \mathrm{O}_{2}$ and (2) similar assays using HRP-dichlorofluorescein have signal responses to organic peroxides up to $97 \%$ lower than to $\mathrm{H}_{2} \mathrm{O}_{2}{ }^{17}$

Briefly, a $5 \mathrm{mg} / \mathrm{L}$ solution of SOA or $\mathrm{PM}_{10}$ filters was irradiated at $311 \mathrm{~nm}$ and sub-samples were taken every $30 \mathrm{~min}, 50 \mu \mathrm{L}$ of horseradish peroxidase mixture was added to these aliquots and the formation of resorufin was quantified with a PDA-UPLC (Waters ACQUITY). A calibration with a freshly opened $\mathrm{H}_{2} \mathrm{O}_{2}$ water solution lead to a correlation between resorufin area and $\mathrm{H}_{2} \mathrm{O}_{2}$ concentration in the sample. The $\mathrm{H}_{2} \mathrm{O}_{2}$ calibration was performed the same day as the experiment. The $\mathrm{H}_{2} \mathrm{O}_{2}$ calibration was also performed in a $5 \mathrm{mg} \mathrm{L}_{\mathrm{C}}^{-1}$ solution of SOA mixtures and PM filters, finding no appreciable influence of these materials on the calibration.

The $\mathrm{H}_{2} \mathrm{O}_{2}$ quantum yields were determined using the following equation:

$\phi_{\mathrm{H}_{2} \mathrm{O}_{2}}=\frac{R_{\mathrm{H}_{2} \mathrm{O}_{2}}}{R_{a b s}}$

where $\mathrm{R}_{\mathrm{H} 2 \mathrm{O} 2}\left(\mathrm{M} \mathrm{s}^{-1}\right)$ is the rate of $\mathrm{H}_{2} \mathrm{O}_{2}$ production and $\mathrm{R}_{\mathrm{abs}}\left(\mathrm{M} \mathrm{s}^{-1}\right)$ is the rate of light absorbance.

$\mathrm{R}_{\mathrm{H} 2 \mathrm{O} 2}$ is the slope of the curve $\left[\mathrm{H}_{2} \mathrm{O}_{2}\right](\mathrm{M})$ versus time (s) and $\mathrm{R}_{\mathrm{abs}}$ is the same rate of light absorbance used for the $\mathrm{OH}$ radical quantum yields. In the case of $\mathrm{H}_{2} \mathrm{O}_{2}$, it is not possible to calculate a steady-state 
concentration due to the long lifetime of $\mathrm{H}_{2} \mathrm{O}_{2}$ in water. $\mathrm{H}_{2} \mathrm{O}_{2}$ concentration indeed increases during the experiment (Figure S8), showing accumulation of this oxidant over time.

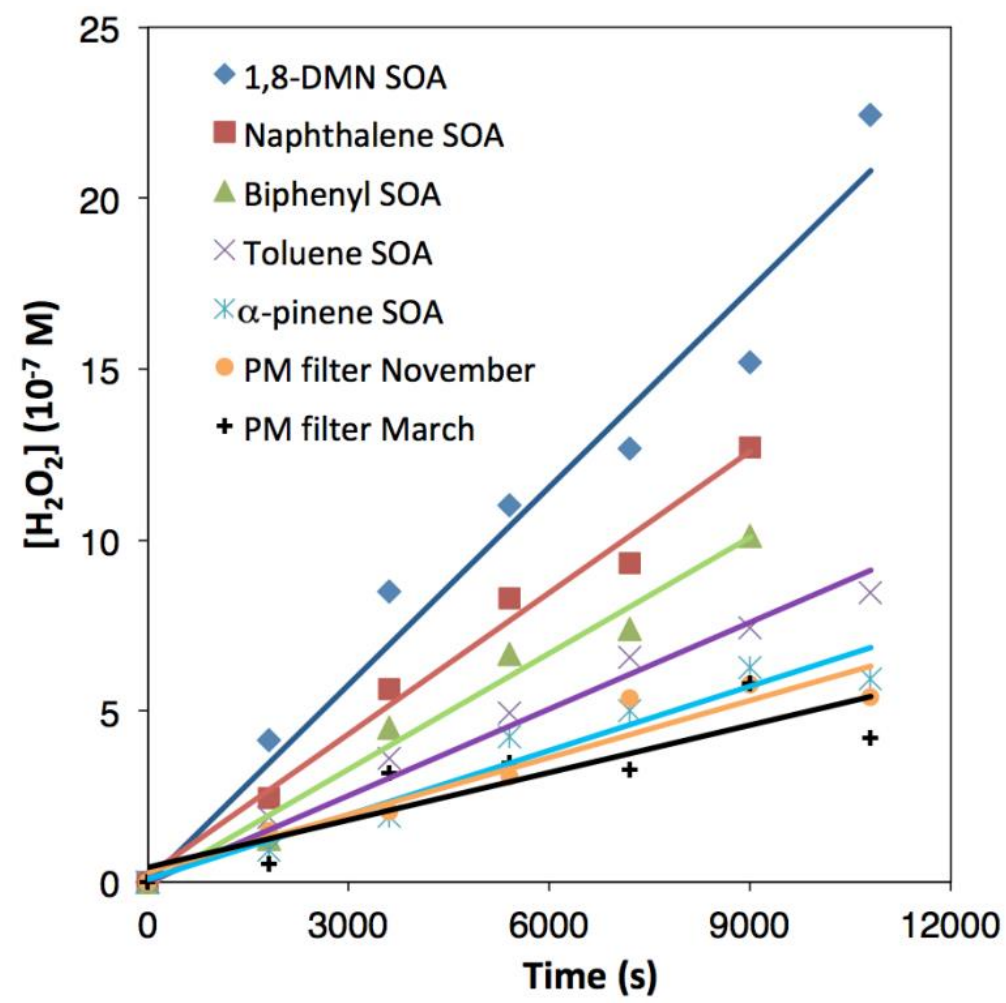

Figure S8. Kinetics of $\mathrm{H}_{2} \mathrm{O}_{2}$ production for SOA samples and $\mathrm{PM}_{10}$ filters.

Table S6. Summary of $\mathrm{R}_{\mathrm{abs}}, \mathrm{R}_{\mathrm{H} 2 \mathrm{O} 2}$, $\phi_{\mathrm{H} 2 \mathrm{O} 2}$ for SOA and $\mathrm{PM}_{10}$ filters. The error associated with $\mathrm{R}_{\mathrm{H} 2 \mathrm{O} 2}$ represents the standard deviation of three measurements, while all the other errors reported are propagated errors.

\begin{tabular}{|c|c|c|c|}
\hline Entry & $\begin{array}{c}\mathbf{R}_{\mathrm{H} 2 \mathrm{O} 2} \\
\left(\mathbf{1 0}^{-11} \mathrm{M} \mathrm{s}^{-1}\right)\end{array}$ & $\begin{array}{c}\mathbf{R}_{\mathrm{abs}} \\
\left(\mathbf{1 0}^{-7} \mathrm{M} \mathrm{s}^{-1}\right)\end{array}$ & $\begin{array}{l}\phi \mathrm{H} 2 \mathrm{O} 2 \\
\left(10^{-4}\right)\end{array}$ \\
\hline 1,8-DMN SOA & $18.6 \pm 1.6$ & $5.3 \pm 0.1$ & $4.5 \pm 0.4$ \\
\hline Naphthene SOA & $11.3 \pm 0.9$ & $3.20 \pm 0.07$ & $3.5 \pm 0.3$ \\
\hline Biphenyl SOA & $9.6 \pm 0.9$ & $3.86 \pm 0.09$ & $2.5 \pm 0.2$ \\
\hline Toluene SOA & $6.9 \pm 0.8$ & $2.61 \pm 0.06$ & $2.6 \pm 0.3$ \\
\hline$\alpha$-pinene SOA & $6.2 \pm 0.5$ & $1.43 \pm 0.07$ & $4.3 \pm 0.4$ \\
\hline PM filter November & $4.7 \pm 0.7$ & $1.19 \pm 0.03$ & $3.9 \pm 0.6$ \\
\hline PM filter March & $3.7 \pm 0.4$ & $0.57 \pm 0.01$ & $6.5 \pm 0.7$ \\
\hline
\end{tabular}

\section{4. $\mathrm{PM}_{10}$ filters correction on ROS steady-state concentrations and quantum yields}

As a control for the $\mathrm{PM}_{10}$ filters, we measured the ROS production of a blank filter. We found the filter to release organic carbon after extraction and to produce ROS under irradiation, however with less efficiency than the PM 10 filter samples. We therefore corrected the $\left[{ }^{1} \mathrm{O}_{2}\right]_{\text {ss }}$ of the two PM10 filter samples by subtracting the FFA $\mathrm{k}_{\text {obs }}$ of the blank filter from the sample filters. The same procedure was employed to correct the $\left[\mathrm{OH}^{\cdot}\right]_{\mathrm{ss}}$, where the hTPA production rate of the blank filter was subtracted from the sample 
filters. Furthermore, ${ }^{1} \mathrm{O}_{2}$ and $\mathrm{OH}$ radical quantum yields were corrected by the subtraction of FFA kobs and hTPA production rates of the blank filter, as well as the UV/Vis absorbance of the blank was used to correct the rate of light absorption of the $\mathrm{PM}_{10}$ filters.

Table S7. $\mathrm{kbss}^{\mathrm{FFA}}, \mathrm{R}_{\mathrm{abs}}{ }^{311}$, RoH, $\mathrm{R}_{\mathrm{abs}}$ used to correct the $\mathrm{PM}_{10}$ filters with the blank filter. The error associated with $\mathrm{k}_{\mathrm{obs}}{ }^{\mathrm{FFA}}$ represents the standard deviation of three measurements, while all the other errors reported are propagated errors.

\begin{tabular}{lc}
\multicolumn{2}{c}{ PM blank filter } \\
\hline $\mathrm{k}_{\text {obs }}{ }^{\text {FFA }}\left(\mathrm{s}^{-1}\right)$ & $(4 \pm 2) \times 10^{-7}$ \\
$\mathrm{R}_{\text {abs }}{ }^{311}$ & $5.4 \times 10^{-3}$ \\
$\mathrm{R}_{\mathrm{OH}}\left(\mathrm{M} \mathrm{s}^{-1}\right)$ & $(1.7 \pm 0.9) \times 10^{-12}$ \\
$\mathrm{R}_{\mathrm{abs}}\left(\mathrm{M} \mathrm{s}^{-1}\right)$ & $(7 \pm 4) \times 10^{-9}$
\end{tabular}




\section{SUVA254 calculation}

The ultraviolet absorbance at $254 \mathrm{~nm}\left(\mathrm{SUVA}_{254}\right)^{21}$ was calculated dividing the absorption coefficient $\left(\mathrm{m}^{-1}\right)$ at $254 \mathrm{~nm}$ by the concentration of the SOA sample $\left(\mathrm{mgC}^{-1}\right)$. Three SOA samples were irradiated for 4 hours at $311 \mathrm{~nm}$ with a SMART narrow-band UVB hand-held lamp and at $365 \mathrm{~nm}$ in a Rayonet photoreactor with 12 light bulbs. The UV-vis absorption spectrum was measured every hour and so the SUVA254 was calculated. The results presented in Table S8 show that SUVA254 values are not significantly changing within 4 hours of irradiation at both wavelengths.

Table S8. SUVA 254 for 1,8-dimethylnaphthalene, biphenyl and toluene SOA, and $\mathrm{PM}_{10}$ filters before and after irradiation at $311 \mathrm{~nm}$ and $365 \mathrm{~nm}$. Due to lack of material, it was possible to calculate SUVA254 of naphthalene SOA only for time 0 hour.

\section{SUVA $254 \mathrm{~L} \mathrm{mgc}^{-1} \mathrm{~m}^{-1}$ (irradiation at 365nm)}

\begin{tabular}{cccccccc}
$\begin{array}{c}\text { time } \\
\text { (h) }\end{array}$ & $\begin{array}{c}\text { 1,8-DMN } \\
\text { SOA }\end{array}$ & $\begin{array}{c}\text { Naphth } \\
\text { SOA }\end{array}$ & $\begin{array}{c}\text { Biphenyl } \\
\text { SOA }\end{array}$ & $\begin{array}{c}\text { Toluene } \\
\text { SOA }\end{array}$ & $\begin{array}{c}\text { o-pinene } \\
\text { SOA }\end{array}$ & $\begin{array}{c}\text { PM filter } \\
\text { November }\end{array}$ & $\begin{array}{c}\text { PM filter } \\
\text { March }\end{array}$ \\
\hline & & & & & & & \\
0 & 2.9 & 3.5 & 4.4 & 2.0 & 0.3 & 1.5 & 1.1 \\
1 & 2.9 & n.d. & 4.2 & 1.9 & n.d. & 1.5 & 1.2 \\
2 & 2.8 & n.d. & 4.2 & 2.2 & n.d. & 1.4 & 1.1 \\
3 & 2.7 & n.d. & 4.1 & 1.9 & n.d. & 1.4 & 1.1 \\
4 & 2.7 & n.d. & 3.9 & 1.9 & n.d. & 1.3 & 1.1
\end{tabular}

\begin{tabular}{|c|c|c|c|c|c|c|c|}
\hline \multirow[b]{2}{*}{0} & \multicolumn{7}{|c|}{ SUVA $_{254} \mathrm{~L} \mathrm{mgc}^{-1} \mathrm{~m}^{-1}$ (irradiation at $311 \mathrm{~nm}$ ) } \\
\hline & 3.3 & 3.5 & 4.5 & 2.1 & 0.3 & 1.5 & 1.2 \\
\hline 1 & 3.3 & n.d. & 4.4 & 2.0 & n.d. & 1.5 & 1.1 \\
\hline 2 & 3.3 & n.d. & 4.2 & 2.1 & n.d. & 1.3 & 1.1 \\
\hline 3 & 3.2 & n.d. & 4.3 & 1.9 & n.d. & 1.3 & 1.1 \\
\hline 4 & 3.5 & n.d. & 4.3 & 2.0 & n.d. & 1.4 & 1.0 \\
\hline
\end{tabular}




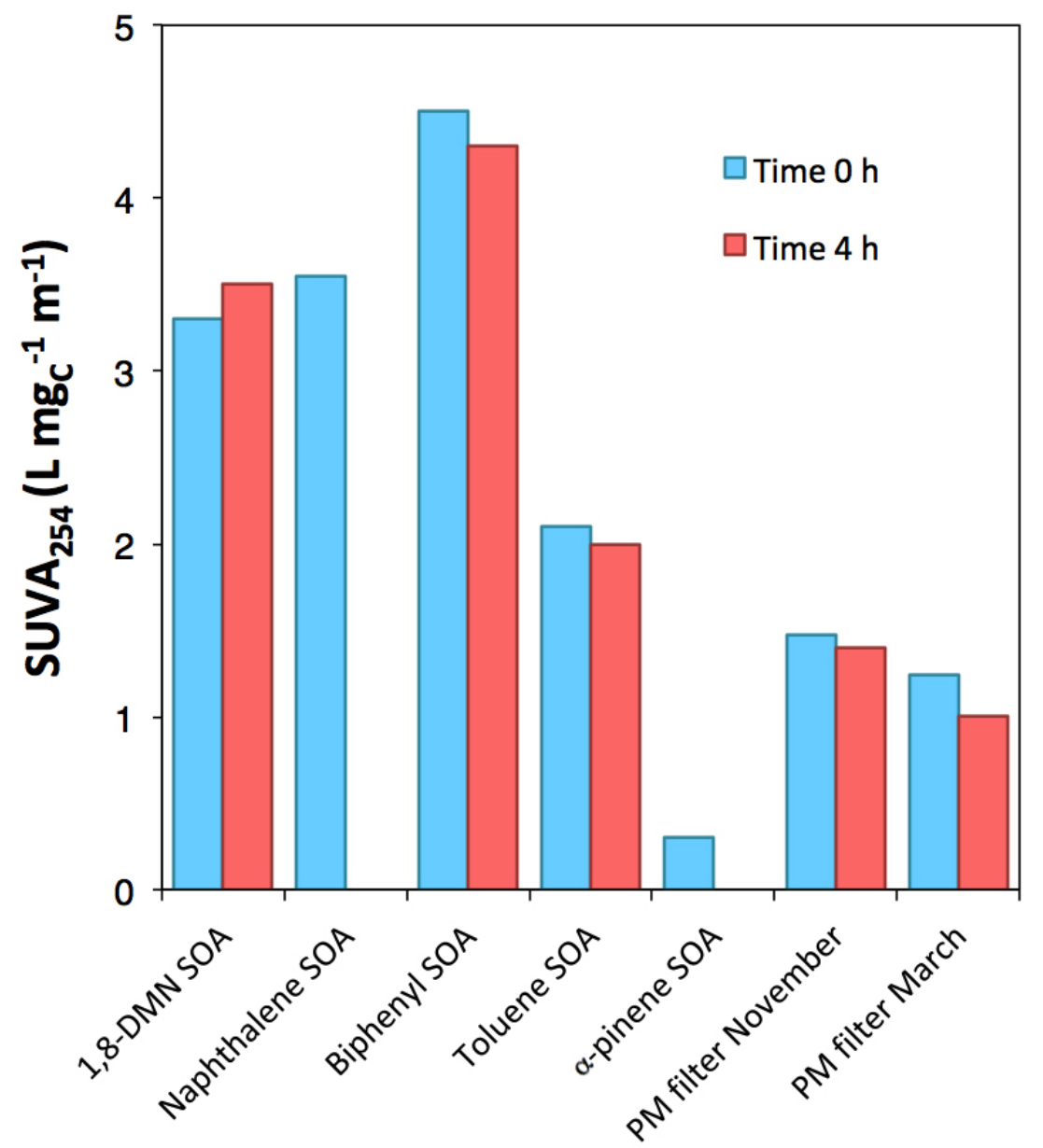

Figure S9: $\mathrm{SUVA}_{254}$ values for each SOA and $\mathrm{PM}_{10}$ extract before and after a $4 \mathrm{~h}$ irradiation at $311 \mathrm{~nm}$.

\section{Mass spectrometry analysis}

SOA extracts were characterized using electrospray ionization and high-resolution mass spectrometry (ESI-HRMS) on an Orbitrap Exactive HRMS (Thermo Scientific). Undiluted samples were infused via syringe pump at $10 \mu \mathrm{L} / \mathrm{min}$. Full-scan, high-resolution $\left(\mathrm{R}=10^{5}\right.$ at $\left.\mathrm{m} / z, 200\right)$ and accurate-mass mass spectra were recorded from $\mathrm{m} / z$ 50-1000 in both ESI(+) and ESI(-). Averaged scans ( 20$)$ were converted to mzML and processed using XCMS with mass spec wavelet peak detection algorithm. Centroid peaks with signal to noise ratios $>3$ were grouped and filled across samples. In addition, background subtraction was performed with the filter blank sample. Molecular formulas were assigned assuming $[\mathrm{M}+\mathrm{H}]^{+}$or $[\mathrm{M}-$ $\mathrm{H}]^{-}$pseudomolecular ions with elemental limitations C[1-50]H[1-150]O[1-50]N[0-3]. Formulas were assigned in two stages. In the first stage, the allowed mass error was set to $20 \mathrm{ppm}$, but assigned formulas were then recursively culled until the range of mass errors was $<10 \mathrm{ppm}$. Next, the average mass error was used to recalibrate $\mathrm{m} / \mathrm{z}$ values assuming that the density of assigned formulas is greatest near the experimental mass error. Finally, molecular formulas were re-assigned with an allowed mass error of 5 ppm.

SOA mixtures were analyzed with HRMS and raw data are presented in Figure S10. We measured the $\mathrm{H}: \mathrm{C}$ and $\mathrm{O}: \mathrm{C}$ ratio in order to estimate the aromaticity and the oxidation state of the mixture before and 
after 4 hours of UVA irradiation. We hypothesize that the chromophores responsible for ${ }^{1} \mathrm{O}_{2}$ production are aromatics produced during the SOA formation process within the smog chamber, and that they are not significantly depleted under UV irradiation. The van Krevelan plots show that after UVA irradiation (red cross), the $\mathrm{H}: \mathrm{C}$ and $\mathrm{O}: \mathrm{C}$ ratio for SOA mixtures do not significantly change from time 0 hours (blue cross) (Figure S12). We also calculated the carbon oxidation state as in previous literature, ${ }^{22}$ and plot it versus the carbon number (Figure S13). Indeed, the carbon oxidation state does not change significantly after irradiation. This evidence suggests that no appreciable oxidation is happening while illumination with UVA light. Figure S11 in the main text displays the aromaticity equivalent $\left(X_{c}\right)$, used to characterize atmospheric particulate matter, ${ }^{23}$ and Figure S14 displays the aromaticity index (AI), used for natural organic matter, ${ }^{24}$ at time 0 and 4 hours. The plots indicate that the presence of large conjugated systems, likely being responsible for the aromatic SOA material's ability to sensitize ${ }^{1} \mathrm{O}_{2}$, is not significantly influenced by UVA irradiation. This result is consistent with the ability of SOA to produce a steady-state concentration of ${ }^{1} \mathrm{O}_{2}$ that does not depend on the experimental irradiation time, although significantly longer times could lead to changes. ${ }^{4}$ In other words, there seems to be evidence for the constant sensitized production of ${ }^{1} \mathrm{O}_{2}$ in the SOA mixtures, but more systematic studies need to be conducted for a deeper understanding of SOA composition. 

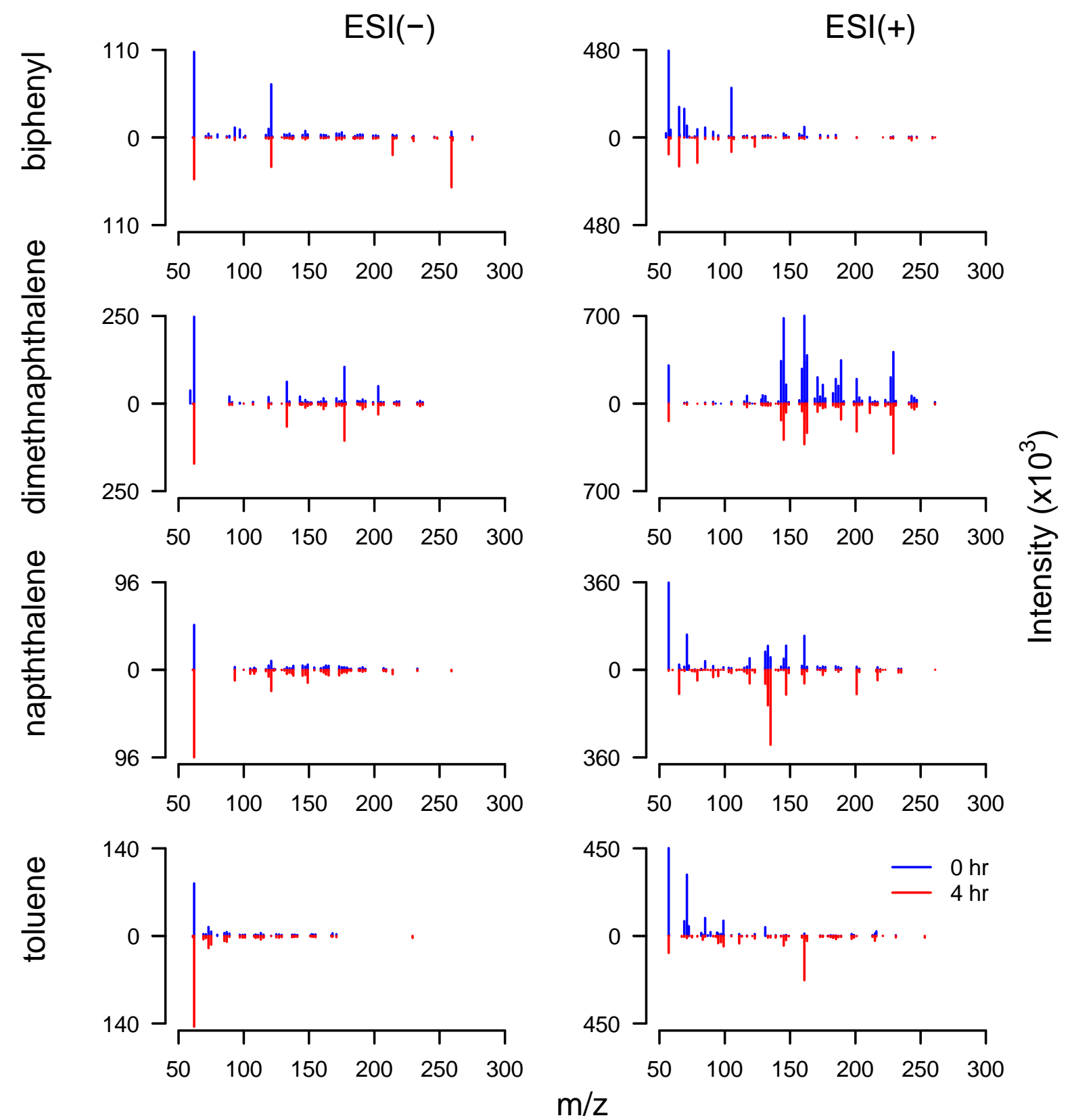

Figure S10. ESI(-) and ESI(+) HRMS of the four SOA samples generated from aromatic precursors before (blue, up) and after (red, down) 4 hours of irradiation at $365 \mathrm{~nm}$. The presence of low molecular weight compounds (below $\mathrm{m} / \mathrm{z} 100$ ) could be the result of fragmentation in the ionization source, but could also indicate that low molecular weight compounds are embedded in SOA particles in the smog chamber and then released when the filters are extracted in water. 

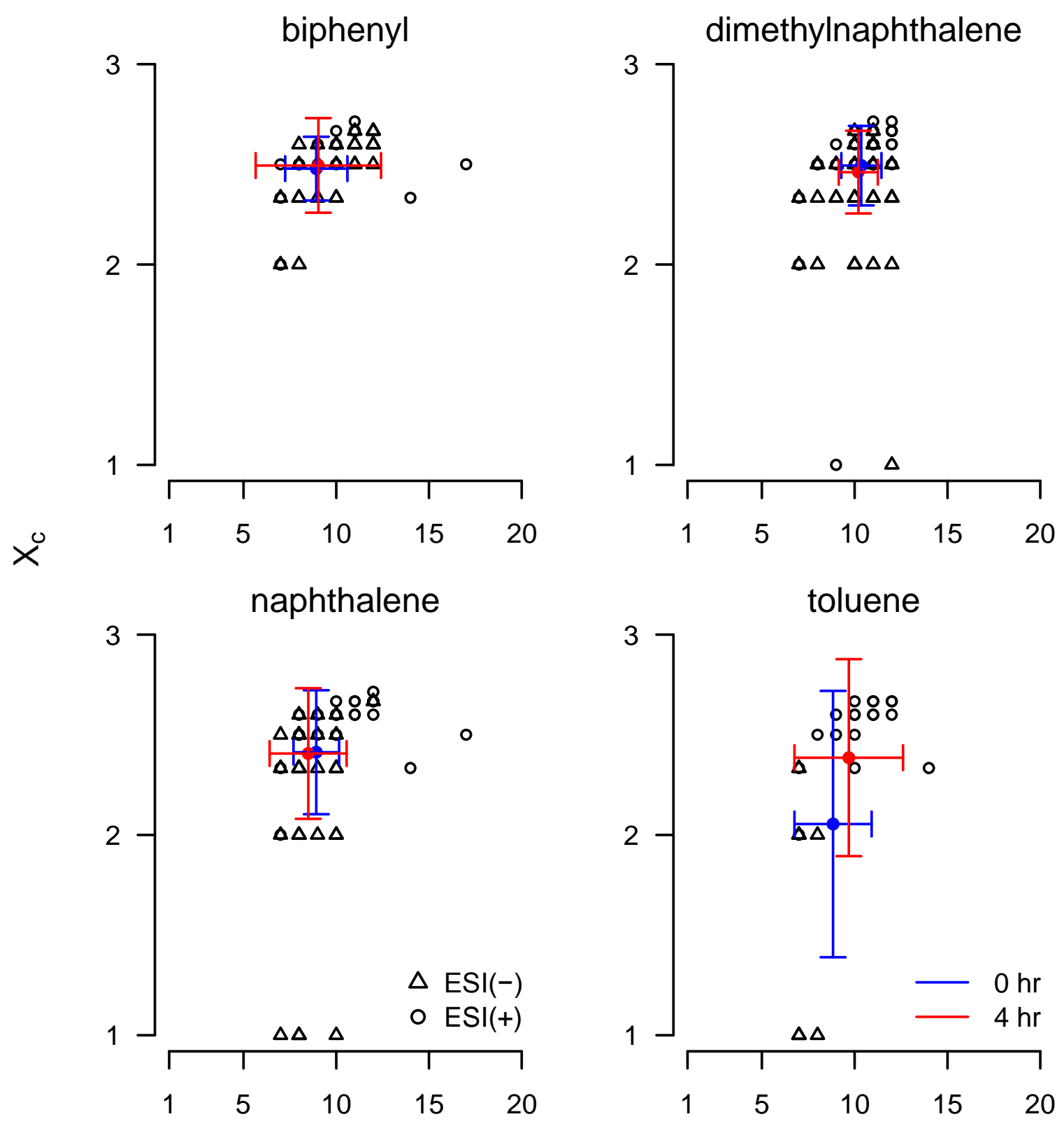

Carbon number

Figure S11: Aromatic equivalent values $\left(X_{c}\right)$ as a function of carbon number for the four anthropogenic SOA extracts shown before and after $4 \mathrm{~h}$ of irradiation at $365 \mathrm{~nm}$. 

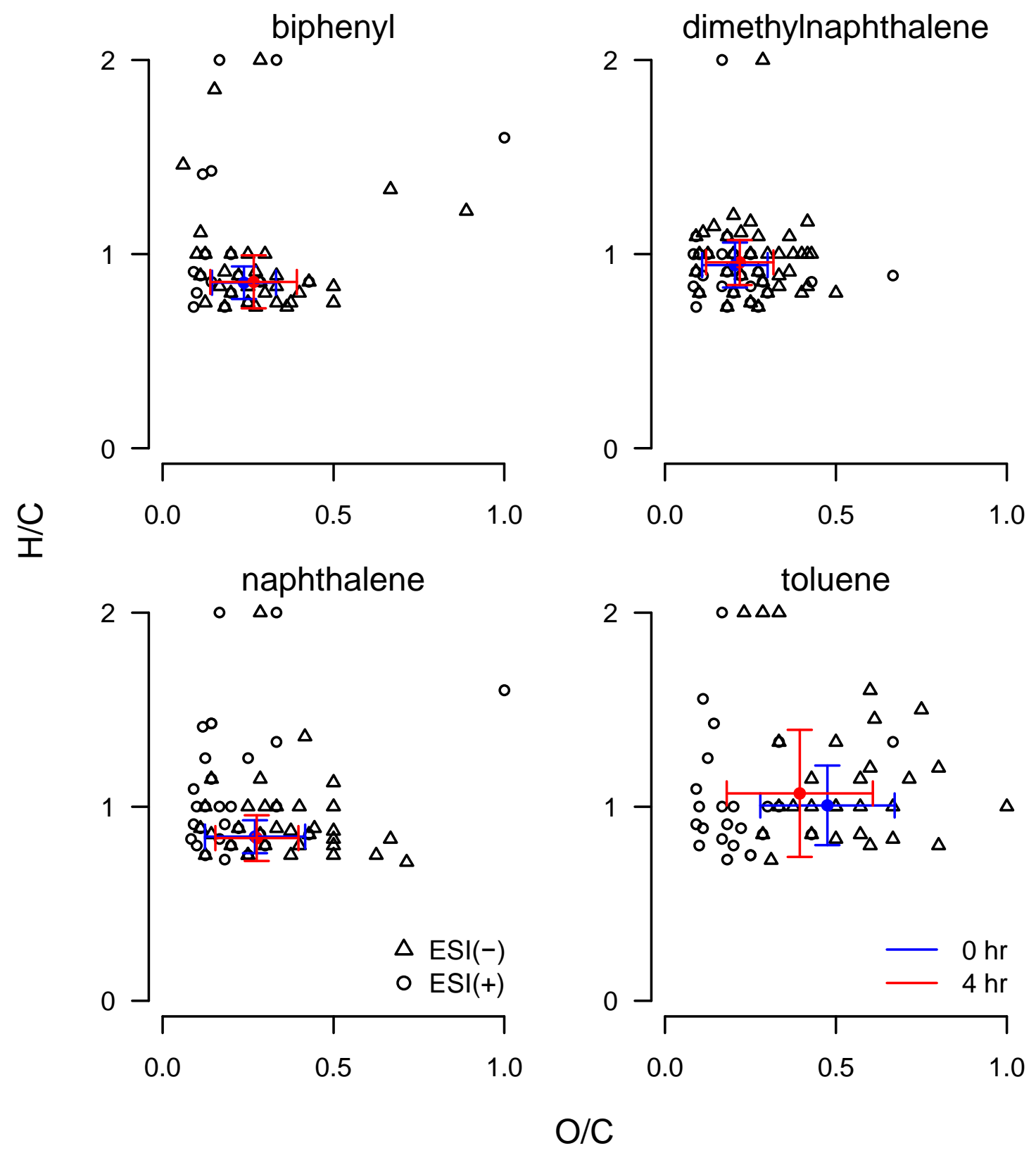

Figure S12. Plots of $\mathrm{H} / \mathrm{C}$ vs $\mathrm{O} / \mathrm{C}$ for the four SOA samples able to sensitize ${ }^{1} \mathrm{O}_{2}$ show no significant change after 4 hours of irradiation. Open triangles and circles represent data from ESI(-) a and ESI(+), respectively. Filled circles indicate the intensity-weighted average for each value at $0 \mathrm{~h}$ (blue) and $4 \mathrm{~h}$ (red). Error bars denote the intensity-weighted standard deviation. 

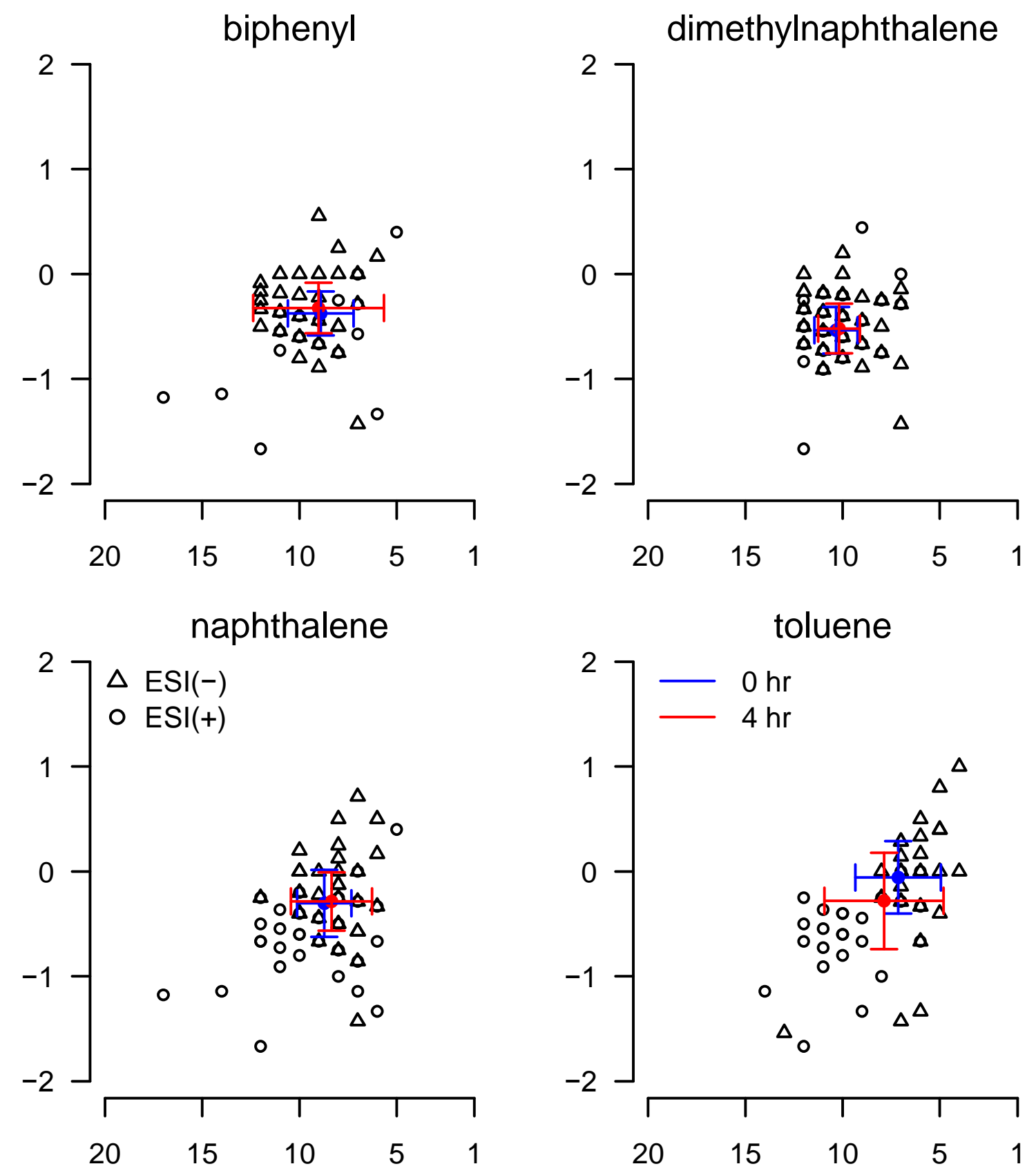

\section{Carbon number}

Figure S13. Plots of the nominal carbon oxidation state vs carbon number for the four SOA samples able to sensitize ${ }^{1} \mathrm{O}_{2}$ show no significant change after 4 hours of irradiation. Open triangles and circles represent data from ESI(-) and ESI(+), respectively. Filled circles indicate the intensity-weighted average for each value at $0 \mathrm{~h}$ (blue) and $4 \mathrm{~h}$ (red). Error bars denote the intensity-weighted standard deviation. 

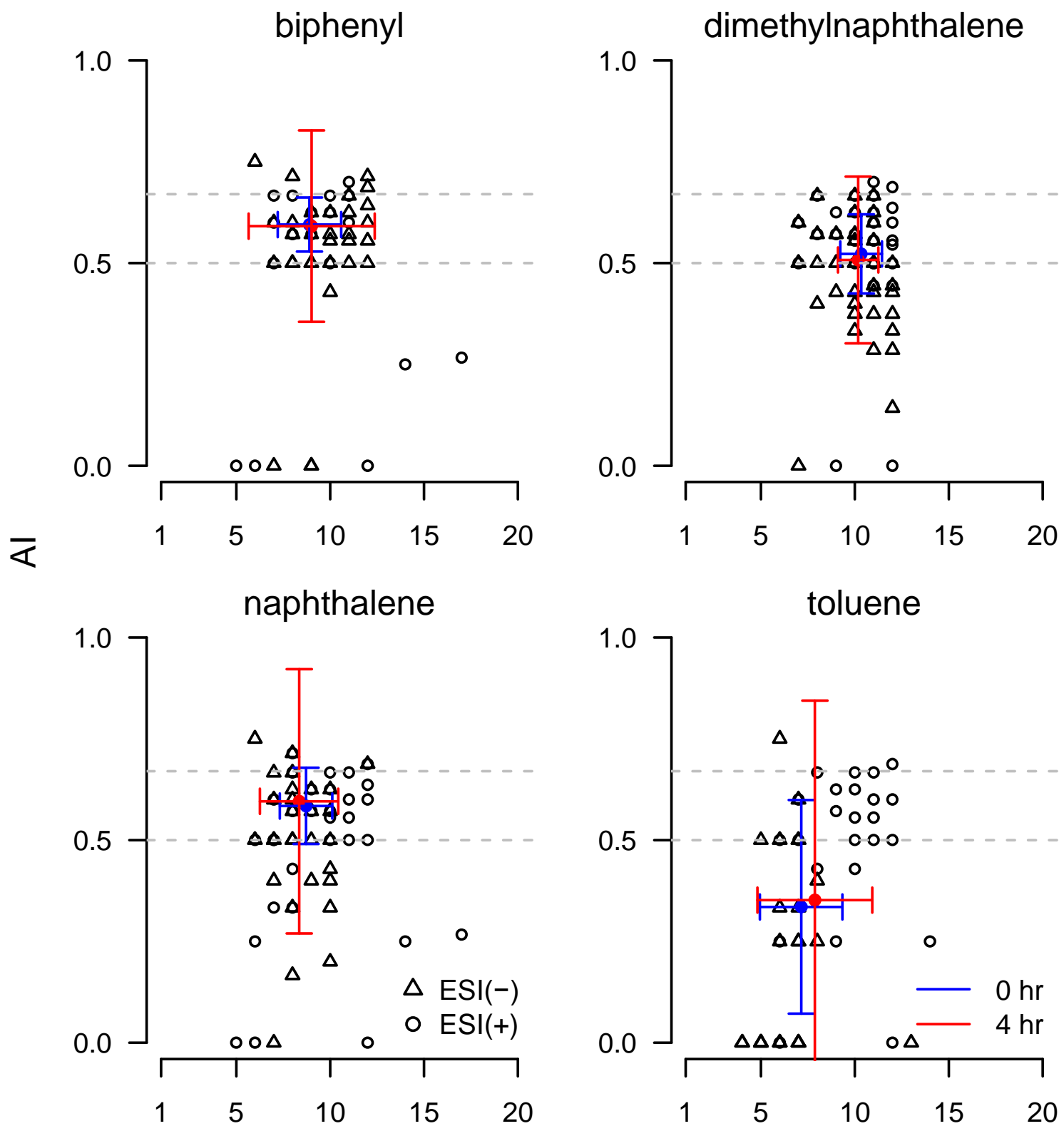

\section{Carbon number}

Figure S14. Aromaticity index (AI, right) plotted versus the carbon number for the four SOA samples able to sensitize ${ }^{1} \mathrm{O}_{2}$. Open triangles and circles represent data from ESI(-) and ESI(+), respectively. Filled circles indicate the intensity-weighted average for each value at $0 \mathrm{~h}$ (blue) and $4 \mathrm{~h}$ (red). Error bars denote the intensity-weighted standard deviation. No significant change is appreciable after irradiation, supporting the hypothesis that the average aromaticity in SOA mixtures is not changing under irradiation. 
7. Kinetic box model calculation

A kinetic box model calculation was performed to assess relative contribution of ${ }^{1} \mathrm{O}_{2}$ and $\mathrm{OH}$ radical to the degradation of pollutants and air tracers. Reaction rate constant used for the calculation were present in the literature and are reported in Table S9.

Table S9. List of previously reported ${ }^{1} \mathrm{O}_{2}$ and $\mathrm{OH}$ radical reaction rate constants with single molecules used for the box model calculation presented in Figure 4 of the main text.

\begin{tabular}{|c|c|c|c|c|}
\hline Compound & $\begin{array}{c}K_{r x n, 102} \\
\left(10^{7} M^{-1} s^{-1}\right) \\
\end{array}$ & $\begin{array}{c}\text { Krxn,OH } \\
\left(10^{9} M^{-1} \mathbf{S}^{-1}\right)\end{array}$ & Ref. ${ }^{1} \mathrm{O}_{2}$ & Ref. OH· \\
\hline Benzimidazole & 0.25 & 7.86 & 25 & 26 \\
\hline Imidazole & 4.00 & 6.40 & 27 & 28 \\
\hline Indole & 4.47 & 13.7 & 29 & 30,31 \\
\hline Vanillin & 0.036 & 0.40 & 32 & 33 \\
\hline Syringol & 3.60 & 58.2 & 34 & 35 \\
\hline 4-Nitrophenol & 0.25 & 4.10 & 36 & 37 \\
\hline Histidine & 7.00 & 4.80 & 38 & 38 \\
\hline Tyrosine & 0.80 & 13.0 & 38 & 38 \\
\hline Tryptophan & 3.40 & 13.0 & 38 & 38 \\
\hline Methionine & 1.60 & 7.40 & 38 & 38 \\
\hline Cysteine & 0.83 & 19.0 & 38 & 38 \\
\hline Resorcinol & 2.00 & 5.80 & 39 & 40 \\
\hline Hydroquinone & 2.50 & 11.0 & 39 & 40 \\
\hline Niclosamide & 2.25 & 7.48 & 41 & 41 \\
\hline
\end{tabular}




\section{References}

(1) Romonosky, D. E.; Ali, N. N.; Saiduddin, M. N.; Wu, M.; Lee, H. J. (Julie); Aiona, P. K.; Nizkorodov, S. A. Effective Absorption Cross Sections and Photolysis Rates of Anthropogenic and Biogenic Secondary Organic Aerosols. Atmos. Environ. 2016, 130, 172-179. https://doi.org/10.1016/j.atmosenv.2015.10.019.

(2) Pang, Y.; Turpin, B. J.; Gundel, L. A. On the Importance of Organic Oxygen for Understanding Organic Aerosol Particles. Aerosol Sci. Technol. 2006, 40 (2), 128-133. https://doi.org/10.1080/02786820500423790.

(3) Il'ina, A. D.; Glazov, A. L.; Semenova, I. V.; Vasyutinskii, O. S. The Influence of Excitation Radiation Parameters on Photosensitized Generation of Singlet Oxygen in Water. Opt. Spectrosc. 2016, 120 (6), 876-880. https://doi.org/10.1134/S0030400X16060084.

(4) Sharpless, C. M.; Aeschbacher, M.; Page, S. E.; Wenk, J.; Sander, M.; McNeill, K. PhotooxidationInduced Changes in Optical, Electrochemical, and Photochemical Properties of Humic Substances. Environ. Sci. Technol. 2014, 48 (5), 2688-2696. https://doi.org/10.1021/es403925g.

(5) Appiani, E.; Ossola, R.; Latch, D. E.; Erickson, P. R.; McNeill, K. Aqueous Singlet Oxygen Reaction Kinetics of Furfuryl Alcohol: Effect of Temperature, PH, and Salt Content. Environ. Sci. Process. Impacts 2017, 19 (4), 507-516. https://doi.org/10.1039/C6EM00646A.

(6) Schmidt, R.; Tanielian, C.; Dunsbach, R.; Wolff, C. Phenalenone, a Universal Reference Compound for the Determination of Quantum Yields of Singlet Oxygen O2(1 $\Delta \mathrm{g})$ Sensitization. J. Photochem. Photobiol. Chem. 1994, 79 (1), 11-17. https://doi.org/10.1016/1010-6030(93)03746-4.

(7) Fresnadillo, D. G.; Lacombe, S. Chapter 6:Reference Photosensitizers for the Production of Singlet Oxygen. In Singlet Oxygen; 2016; pp 105-143. https://doi.org/10.1039/9781782622208-00105.

(8) Segado, M.; Reguero, M. Mechanism of the Photochemical Process of Singlet Oxygen Production by Phenalenone. Phys. Chem. Chem. Phys. 2011, 13 (9), 4138-4148. https://doi.org/10.1039/C0CP01827A.

(9) Oliveros, E.; Bossmann, S. H.; Nonell, S.; Martí, C.; Heit, G.; Tröscher, G.; Neuner, A.; Martínez, C.; Braun, A. M. Photochemistry of the Singlet Oxygen [O2 $(1 \Delta \mathrm{g})]$ Sensitizer Perinaphthenone (Phenalenone) in N,N'-Dimethylacetamide and 1,4-Dioxane. New J. Chem. 1999, 23 (1), 85-93. https://doi.org/10.1039/A804054K.

(10) Arnbjerg, J.; Paterson, M. J.; Nielsen, C. B.; Jørgensen, M.; Christiansen, O.; Ogilby, P. R. One- and Two-Photon Photosensitized Singlet Oxygen Production: Characterization of Aromatic Ketones as Sensitizer Standards. J. Phys. Chem. A 2007, 111 (26), 5756-5767. https://doi.org/10.1021/jp0711971.

(11) Buxton, G. V.; Greenstock, C. L.; Helman, W. P.; Ross, A. B. Critical Review of Rate Constants for Reactions of Hydrated Electrons, Hydrogen Atoms and Hydroxyl Radicals $\left(\cdot \mathrm{OH} / \cdot \mathrm{O}^{-}\right.$in Aqueous Solution. J. Phys. Chem. Ref. Data 1988, 17 (2), 513-886. https://doi.org/10.1063/1.555805.

(12) Kaur, R.; Labins, J. R.; Helbock, S. S.; Jiang, W.; Bein, K. J.; Zhang, Q.; Anastasio, C. Photooxidants from Brown Carbon and Other Chromophores in Illuminated Particle Extracts. Atmospheric Chem. Phys. 2019, 19 (9), 6579-6594. https://doi.org/10.5194/acp-19-6579-2019.

(13) Davis, C. A.; McNeill, K.; Janssen, E. M.-L. Non-Singlet Oxygen Kinetic Solvent Isotope Effects in Aquatic Photochemistry. Environ. Sci. Technol. 2018, 52 (17), 9908-9916. https://doi.org/10.1021/acs.est.8b01512.

(14) Page, S. E.; Arnold, W. A.; McNeill, K. Terephthalate as a Probe for Photochemically Generated Hydroxyl Radical. J. Environ. Monit. 2010, 12 (9), 1658. https://doi.org/10.1039/c0em00160k.

(15) Zhou, X.; Mopper, K. Determination of Photochemically Produced Hydroxyl Radicals in Seawater and Freshwater. Mar. Chem. 1990, 30, 71-88. https://doi.org/10.1016/0304-4203(90)90062-H.

(16) Laszakovits, J. R.; Berg, S. M.; Anderson, B. G.; O’Brien, J. E.; Wammer, K. H.; Sharpless, C. M. P-Nitroanisole/Pyridine and p-Nitroacetophenone/Pyridine Actinometers Revisited: Quantum Yield in Comparison to Ferrioxalate. Environ. Sci. Technol. Lett. 2017, 4 (1), 11-14. https://doi.org/10.1021/acs.estlett.6b00422. 
(17) Badali, K. M.; Zhou, S.; Aljawhary, D.; Antiñolo, M.; Chen, W. J.; Lok, A.; Mungall, E.; Wong, J. P. S.; Zhao, R.; Abbatt, J. P. D. Formation of Hydroxyl Radicals from Photolysis of Secondary Organic Aerosol Material. Atmos Chem Phys 2015, 15 (14), 7831-7840. https://doi.org/10.5194/acp-15-7831-2015.

(18) Tong, H.; Lakey, P. S. J.; Arangio, A. M.; Socorro, J.; Kampf, C. J.; Berkemeier, T.; Brune, W. H.; Pöschl, U.; Shiraiwa, M. Reactive Oxygen Species Formed in Aqueous Mixtures of Secondary Organic Aerosols and Mineral Dust Influencing Cloud Chemistry and Public Health in the Anthropocene. Faraday Discuss. 2017, 200 (0), 251-270. https://doi.org/10.1039/C7FD00023E.

(19) Towne, V.; Will, M.; Oswald, B.; Zhao, Q. Complexities in Horseradish Peroxidase-Catalyzed Oxidation of Dihydroxyphenoxazine Derivatives: Appropriate Ranges for $\mathrm{PH}$ Values and Hydrogen Peroxide Concentrations in Quantitative Analysis. Anal. Biochem. 2004, 334 (2), 290 296. https://doi.org/10.1016/j.ab.2004.07.037.

(20) Zhao, B.; Summers, F. A.; Mason, R. P. Photooxidation of Amplex Red to Resorufin: Implications of Exposing the Amplex Red Assay to Light. Free Radic. Biol. Med. 2012, 53 (5), 1080-1087. https://doi.org/10.1016/j.freeradbiomed.2012.06.034.

(21) Weishaar, J. L.; Aiken, G. R.; Bergamaschi, B. A.; Fram, M. S.; Fujii, R.; Mopper, K. Evaluation of Specific Ultraviolet Absorbance as an Indicator of the Chemical Composition and Reactivity of Dissolved Organic Carbon. Environ. Sci. Technol. 2003, 37 (20), 4702-4708. https://doi.org/10.1021/es030360x.

(22) Kroll, J. H.; Donahue, N. M.; Jimenez, J. L.; Kessler, S. H.; Canagaratna, M. R.; Wilson, K. R.; Altieri, K. E.; Mazzoleni, L. R.; Wozniak, A. S.; Bluhm, H.; et al. Carbon Oxidation State as a Metric for Describing the Chemistry of Atmospheric Organic Aerosol. Nat. Chem. 2011, 3 (2), 133-139. https://doi.org/10.1038/nchem.948.

(23) Yassine, M. M.; Harir, M.; Dabek-Zlotorzynska, E.; Schmitt-Kopplin, P. Structural Characterization of Organic Aerosol Using Fourier Transform Ion Cyclotron Resonance Mass Spectrometry: Aromaticity Equivalent Approach: Characterization of Organic Aerosol Using FTICRMS. Rapid Commun. Mass Spectrom. 2014, 28 (22), 2445-2454. https://doi.org/10.1002/rcm.7038.

(24) Koch, B. P.; Dittmar, T. From Mass to Structure: An Aromaticity Index for High-Resolution Mass Data of Natural Organic Matter. Rapid Commun. Mass Spectrom. 2016, 30 (1), 250-250. https://doi.org/10.1002/rcm.7433.

(25) Escalada, J. P.; Pajares, A.; Gianotti, J.; Massad, W. A.; Bertolotti, S.; Amat-Guerri, F.; García, N. A. Dye-Sensitized Photodegradation of the Fungicide Carbendazim and Related Benzimidazoles. Chemosphere 2006, 65 (2), 237-244. https://doi.org/10.1016/j.chemosphere.2006.02.057.

(26) Abdelraheem, W. H. M.; He, X.; Komy, Z. R.; Ismail, N. M.; Dionysiou, D. D. Revealing the Mechanism, Pathways and Kinetics of UV 254nm /H 2 O 2 -Based Degradation of Model Active Sunscreen Ingredient PBSA. Chem. Eng. J. 2016, 288, 824-833. https://doi.org/10.1016/j.cej.2015.12.046.

(27) Kraljić, I.; Sharpatyi, V. A. Determination of Singlet Oxygen Rate Constants in Aqueous Solutions. Photochem. Photobiol. 1978, 28 (4-5), 583-586. https://doi.org/10.1111/j.17511097.1978.tb06973.x.

(28) Ching, T.-L.; Haenen, G. R. M. M.; Bast, A. Cimetidine and Other H2 Receptor Antagonists as Powerful Hydroxyl Radical Scavengers. Chem. Biol. Interact. 1993, 86 (2), 119-127. https://doi.org/10.1016/0009-2797(93)90116-G.

(29) Mercader, A. G.; Duchowicz, P. R.; Fernández, F. M.; Castro, E. A.; Cabrerizo, F. M.; Thomas, A. H. Predictive Modeling of the Total Deactivation Rate Constant of Singlet Oxygen by Heterocyclic Compounds. J. Mol. Graph. Model. 2009, 28 (1), $12-19$. https://doi.org/10.1016/j.jmgm.2009.03.002.

(30) Iddon, B.; Phillips, G. O.; Robbins, K. E.; Davies, J. V. Radiation Chemistry of Aqueous Solutions of Indole and Its Derivatives. J. Chem. Soc. B Phys. Org. 1971, No. 0, 1887-1892. https://doi.org/10.1039/J29710001887. 
(31) Kawanishi, S.; Sakurai, H. Differential Anti-Lipid Peroxidative Activity of Melatonin. Naturwissenschaften 2002, 89 (1), 31-33.

(32) Li, Y. J.; Huang, D. D.; Cheung, H. Y.; Lee, A. K. Y.; Chan, C. K. Aqueous-Phase Photochemical Oxidation and Direct Photolysis of Vanillin - a Model Compound of Methoxy Phenols from Biomass Burning. Atmospheric Chem. Phys. 2014, 14 (6), 2871-2885. https://doi.org/10.5194/acp14-2871-2014.

(33) Machado, A. E. H.; Gomes, A. J.; Campos, C. M. F.; Terrones, M. G. H.; Perez, D. S.; Ruggiero, R.; Castellan, A. Photoreactivity of Lignin Model Compounds in the Photobleaching of Chemical Pulps 2. Study of the Degradation of 4-Hydroxy-3-Methoxy-Benzaldehyde and Two Lignin Fragments Induced by Singlet Oxygen. J. Photochem. Photobiol. Chem. 1997, 110 (1), 99-106. https://doi.org/10.1016/S1010-6030(97)00161-5.

(34) Tratnyek, P. G.; Hoigne, J. Oxidation of Substituted Phenols in the Environment: A QSAR Analysis of Rate Constants for Reaction with Singlet Oxygen. Environ. Sci. Technol. 1991, 25 (9), 15961604. https://doi.org/10.1021/es00021a011.

(35) Lauraguais, A.; Coeur-Tourneur, C.; Cassez, A.; Seydi, A. Rate Constant and Secondary Organic Aerosol Yields for the Gas-Phase Reaction of Hydroxyl Radicals with Syringol (2,6Dimethoxyphenol). $\quad$ Atmos. $\quad$ Environ. $2012, \quad$ 55, 43 -48. https://doi.org/10.1016/j.atmosenv.2012.02.027.

(36) Scully, F. E.; Hoigné, J. Rate Constants for Reactions of Singlet Oxygen with Phenols and Other Compounds in Water. Chemosphere 1987, 16 (4), 681-694. https://doi.org/10.1016/00456535(87)90004-X.

(37) Biswal, J.; Paul, J.; Naik, D. B.; Sarkar, S. K.; Sabharwal, S. Radiolytic Degradation of 4 Nitrophenol in Aqueous Solutions: Pulse and Steady State Radiolysis Study. Radiat. Phys. Chem. 2013, 85, 161-166. https://doi.org/10.1016/j.radphyschem.2013.01.003.

(38) Lundeen, R. A.; Janssen, E. M.-L.; Chu, C.; Mcneill, K. Environmental Photochemistry of Amino Acids, Peptides and Proteins. Chim. Int. J. Chem. 2014, 68 (11), 812-817. https://doi.org/10.2533/chimia.2014.812.

(39) Mártire, D. O.; Braslavsky, S. E.; García, N. A. Sensitized Photo-Oxidation of Dihydroxybenzenes and Chlorinated Derivatives. A Kinetic Study. J. Photochem. Photobiol. Chem. 1991, 61 (1), 113124. https://doi.org/10.1016/1010-6030(91)85079-V.

(40) Smith, J. D.; Kinney, H.; Anastasio, C. Aqueous Benzene-Diols React with an Organic Triplet Excited State and Hydroxyl Radical to Form Secondary Organic Aerosol. Phys. Chem. Chem. Phys. 2015, 17 (15), 10227-10237. https://doi.org/10.1039/C4CP06095D.

(41) McConville, M. B.; Mezyk, S. P.; Remucal, C. K. Indirect Photodegradation of the Lampricides TFM and Niclosamide. Environ. Sci. Process. Impacts 2017, 19 (8), 1028-1039. https://doi.org/10.1039/C7EM00208D. 